\title{
Geosmithia Species Associated With Bark Beetles From Southern China, With the Description of Four New Species
}

\author{
Xiuyu Zhang \\ Shandong Normal University \\ You Li \\ Fujian Agriculture and Forestry University \\ Meixue Dai \\ Shandong Normal University \\ Hongli Si \\ Shandong Normal University \\ Guoyan Zhao \\ Shandong Normal University \\ Miroslav Kolařik \\ Czech Academy of Sciences: Akademie ved Ceske republiky \\ Jiri Hulcr \\ University of Florida \\ Xiaoqian Jiang \\ Shandong Normal University \\ Runlei Chang ( $\sim$ runlei.chang@163.com) \\ Shandong Normal University https://orcid.org/0000-0001-6613-9062
}

\section{Research}

Keywords: fungal community, symbiosis, four new taxa

Posted Date: May 26th, 2021

DOl: https://doi.org/10.21203/rs.3.rs-558245/v1

License: @ (1) This work is licensed under a Creative Commons Attribution 4.0 International License. Read Full License 


\section{Abstract}

Fungi of the genus Geosmithia are frequently associated with bark beetles that feed on phloem on various woody hosts. Most studies on Geosmithia were carried out in North and South America and Europe, with only two species were reported from Taiwan, China. The aim of this study was to investigate the diversity of Geosmithia species in southern China. Field surveys in Guangdong, Guangxi, Hunan, Jiangxi and Shanghai yielded a total of 76 fungal isolates from six beetle species. Isolates were grouped based on morphology. The ITS, $\beta$-tubulin and elongation factor 1 -a gene regions of representatives of each group were sequenced. Phylogenetic trees were constructed based on those sequences. In total five species were identified, with one previously described species G. putterillii and four new species which were described as G. jiulianshanensis, G. jiangxiensis, G. formosana, and G. pulverea (Geosmithia sp. 3 and Geosmithia sp. 23) sp. nov., in this paper.

\section{Introduction}

Members of Geosmithia are widely distributed fungal associates of phloem- and xylem-feeding beetles (Kolařík et al. 2007, 2017; Lin et al. 2016; Pitt 1979), such as species in Bostrichidae and Curculionidae-Scolytinae (Coleoptera) (Juzwik et al. 2015; Kolařík et al. 2017). Geosmithia species are predominantly isolated from phloem-feeding bark beetles on broadleaved and conifer trees although they have been documented from many other substrates including soil (Kolarík et al. 2004), seed-feeding beetles (Huang et al. 2017), animal skin (Crous et al. 2018), indoor environment (Crous et al. 2018), insect-free plant tissues (McPherson et al. 2013), and food materials (Pitt and Hocking 2012). To date, almost 60 phylogenetic, and 21 formally described Geosmithia species have been recognized (Strzałka et al. 2021).

Geosmithia is similar to Penicillium and Paecilomyces in morphology, but it can be distinguished by the combination of stipe with or without curved basal cell, verrucous conidiophores (incl. phialide), cylindrical phialide shape with very short and cylindrical neck (collula) and by ellipsoidal or cylindrical conidia (except of globose conidia in G. eupagioceri and G. microcorthyli). Colony color could be in shades of white, yellow, brown or red, but newer bluish green or green (Kolarík et al. 2004; Kolařík and Kirkendall 2010).

The spores of Geosmithia may be transmitted by attaching to the surface of beetle vector, but the ecological role of most Geosmithia species in symbiosis with bark beetles is still unclear. Some species serve as a main food source or supplementary nutrition for the beetles (Kolařik and Kirkendall 2010; Machingambi et al. 2014), but most are probably commensals with minimal or no benefit to the beetle (Veselská et al. 2019) because the vector beetles show neither any apparent morphological adaptation nor nutrient dependence (Huang et al. 2017; Huang et al. 2019). Some Geosmithia species exhibit extracellular antimicrobial and antifungal metabolites but their ecological implications are unknown (Stodůlková et al. 2009; Veselská et al. 2019).

Some Geosmithia species can cause serious tree diseases. One example is the Thousand cankers disease (TCD) of walnuts caused by G. morbida (Kolařík et al. 2011). Following high density colonization by its beetle vector, the walnut twig beetle (WTB, Pityophthorus juglandis), in the phloem of walnut (Juglans spp.) or wingnut (Pterocarya spp.) trees, G. morbida causes numerous small lesions which eventually girdle the vascular tissue (Hishinuma et al. 2015; Kolařik et al. 2011; Tisserat et al. 2009; Seybold et al. 2013; Utley et al. 2013). TCD has affected many walnut trees in North America, especially in the western United States (Tisserat et al. 2009; Tisserat et al. 2011), and has recently been detected in Europe (Montecchio et al. 2014). Another mildly pathogenic specie Geosmithia sp. 41 causes mild pathogenicity in Quercus argifolia (Lynch et al. 2014).

After the discovery of the Geosmithia-beetle association (Kirschner 2001) there has been an accumulation of reports describing Geosmithia fungi from phloem-feeding bark beetles around the world (Huang et al. 2019; Jankowiak et al. 2014; Kolařík and Jankowiak 2013; Kolařík et al. 2004, 2005, 2007, 2008; Kubátová et al. 2004; Machingambi et al. 2014; McPherson et al. 2013; Pepori et al. 2015; Strzalka et al. 2021). Fungal communities associated with phloem infected bark beetles are formed by a variety of biological and abiotic factors. The tree host is one of the most important selection factors (Skelton et al. 2019). Like other beetle-vectored fungi such as the ophiostomatoid fungi (Seifert et al. 2013), Geosmithia species display variable degrees of specificity to their beetle vectors and tree hosts, ranging from generalists to single-species specialists (Kolařík and Jankowiak 2013; Kolařik et al. 2008, 2017; Jankowiak et al. 2014; Veselská et al. 2019). Other factors affecting the fungal community structure include beetle ecology, the surrounding host tree community, and climatic factors (Jankowiak et al. 2014; Six and Bentz 2007). These factors also influence the communities of Geosmithia, most notably by the fact that different beetles coinfesting the same host tree have similar Geosmithia assemblages (Kolařík et al. 2008; Machingambi et al. 2014).

At present, most of studies of Geosmithia were conducted from North and South America and Europe, but the mycoflora of Asian bark beetles remains understudied. The purpose of this study is to investigate the Geosmithia species from southern China using phylogenetic analysis and morphological and physiological features to fill the gap in our understanding of the global Geosmithia diversity.

\section{Materials And Methods}

\section{Sampling, isolating, and preserving of fungal isolates.}

The beetle gallery samples were collected in Guangdong, Guangxi, Hunan, Jiangxi and Shanghai Province from plant hosts of Altingia gracilipes (Altingiaceae), Gnetum luofuense (Gnetaceae), Lauraceae sp., Liquidambar formosana (Altingiaceae), L. styraciflua (Altingiaceae) and Ulmus sp. (Ulmaceae) and kept individually in sealable bags. Adult beetles were individually placed in Eppendorf tubes. Both galleries and adult beetles were kept at $4^{\circ} \mathrm{C}$ for further isolation. The beetle vectors were Acanthotomicus suncei (Curculionidae-Scolytinae), Scolytus jiulianshanensis (Curculionidae-Scolytinae), Crossotarsus emancipatus (Curculionidae-Platypodinae), Dinoderus sp. L489 (Bostrichidae), Microperus sp. L589 (Curculionidae-Scolytinae) and Phloeosinus sp. (Curculionidae) (Table 1). The fungal isolates were obtained by using method of scraping wood tissue from the beetle galleries and inoculated on $2 \%$ malt extract agar (MEA: $20 \mathrm{~g}$ agar [Solarbio, China], $20 \mathrm{~g}$ malt extract [Hopebio, China], $1 \mathrm{~L}$ deionized water). The cultures were purified by hyphal-tip subculturing and incubated at $25{ }^{\circ} \mathrm{C}$. All the cultures obtained in this study were deposited in culture collection (SNM) of Shandong Normal University, Jinan, Shandong 
province, China. Isolates linked to type specimens of the fungal species were deposited in the China General Microbiological Culture Collection Center (CGMCC), Beijing, China. Holotype specimens (dry cultures) were deposited in the Herbarium Mycologicum, Academiae Sinicae (HMAS), Beijing, China.

\section{DNA extraction, amplification, and sequencing.}

DNA was extracted by scraping fresh fungal tissue from pure cultures and adding to $50 \mu \mathrm{L}$ extraction solution of the PrepMan Ultra Sample Preparation Reagent (Applied Biosystems, Foster City, CA). Samples were vortexed after incubated at $100{ }^{\circ} \mathrm{C}$ for $10 \mathrm{~min}$ and then centrifuged at $5000 \mathrm{rpm}$ for $5 \mathrm{~min}$. The supernatant was transferred to a new Eppendorf tube and used as template for polymerase chain reaction (PCR) amplification.

The rDNA region of the ITS1-5.8S-ITS2, internal transcribed spacer ( ITS), was amplified using the primer pair of ITS1-F (Gardes and Bruns 1993) and ITS4 (White et al. 1990). Translation elongation factor 1-a gene (TEF1-a) was amplified using primer pair of EF1-983F and EF1-2218R (Rehner and Buckley 2005). $\beta$-tubulin (TUB2) was amplified by using T10 and Bt2b (Glass and Donaldson 1995; O'Donnell and Cigelnik 1997). PCR amplification was carried out in a final $25 \mu \mathrm{L}$ PCR reaction mixture consisting of 50-100 ng template DNA, $1.25 \mathrm{U}$ Taq polymerase (Vazyme Biotech Co., Ltd, China), $200 \mu \mathrm{M}$ dNTP, $0.5 \mu \mathrm{M}$ of each primer, and $5 \%\left(\mathrm{v} / \mathrm{v}\right.$ ) dimethyl sulfoxide (DMSO). The PCR conditions were as follows: $95^{\circ} \mathrm{C}$ for 3 min, followed by 30 cycles of $95^{\circ} \mathrm{C}$ for 1 min, $50-55^{\circ} \mathrm{C}$ for 1 min, and $72^{\circ} \mathrm{C}$ for $1 \mathrm{~min}$. The final extension step was $72^{\circ} \mathrm{C}$ for $10 \mathrm{~min}$. The amplified products were sequenced in Sangon Biotech, Qingdao, Shandong province, China.

\section{DNA sequence analyses}

The sequences obtained using the forward and reverse primers were aligned in Geneious version 10.2.2 (Biomatters, Auckland, New Zealand). Reference sequences of Geosmithia species were retrieved from GenBank (Table 2). Emericellopsis pallida CBS 490.71 was chosen as the phylogenetic outgroup. Sequences were aligned by using the online version of MAFFT v. 7 (Katoh and Standley 2013) with default setting. The best nucleotide substitution model for each partition was determined in jModelTest v. 2.1.1 (Darriba et al. 2012). Maximum likelihood (ML) phylogenetic analyses were conducted in the CIPRES Science Gateway (Miller et al. 2010) using RAxML v. 8.2.2 (Stamatakis 2014) with recommended partition parameters to assess the tree topology and bootstrap values from 1000 replicate searches. Bayesian inference (BI) was estimated in the CIPRES Science Gateway (Miller et al. 2010) using MrBayes 3.2.7a (Ronquist et al. 2012). MCMC runs of four chains were executed simultaneously from a random starting tree for five million generations, every 100 generations were sampled resulting in 50000 trees, and 12500 trees were discarded during burn-in. Posterior probabilities were estimated from the retained 37500 trees. Phylogenetic trees were visualized and edited in FigTree v. 1.4.3. The final alignments used in this study have been submitted to TreeBase (https://www.treebase.org/, nos.: 28242).

\section{Morphological study}

Morphological characters were observed and recorded using the Olympus BX61 microscope (Olympus Corporation, Japan). The images were analyzed using ImageJ (https://imagej.net/). At least 50 measurements for each of the structures were measured. The results of the calculation are expressed as (minimum -) mean minus standard deviation - mean plus standard deviation - (- maximum).

\section{Growth study}

Three independently isolated strains of each novel taxon were randomly selected for growth experiments. The active growing edge mycelia were inoculated at the centers of $90 \mathrm{~mm}$ Petri dishes containing $2 \%$ MEA and incubated in darkness at temperatures ranging from 5 to $35^{\circ} \mathrm{C}$ for 8 days at $5{ }^{\circ} \mathrm{C}$ intervals, and each temperature has three duplicates. Colony diameters were measured every 2 days and then calculated the optimum temperature of growth for each species and the high and low temperature conditions of growth.

\section{Results}

\section{Collection of samples and isolation of fungi}

A total of 76 strains in the genus Geosmithia were isolated from 6 beetle species and their galleries. The 73 strains were from the galleries and three strains (SNM887, SNM886, SNM885) from the beetles. Sixty-three strains were from Jiangxi, nine from Shanghai, two from Guangxi, one from Guangdong and one from Hunan (Table 1).

\section{Phylogenetic analysis}

The preliminary classification was carried out by BLAST on NCBI GenBank using the ITS marker. Subsequently, 20 representative strains were selected for multi-gene phylogenetic analysis and 10 strains were screened for morphological studies (Table 2). Aligned sequences including gaps yielded 562 characters for ITS, 907 characters for TEF1-a, and 632 characters for TUB2. The best substitution model for ITS, TEF1-a and TUB2 was GTR + I + G. For all datasets (ITS, TUB2, TEF1-a), ML, MP and Bayesian inference produced nearly identical topologies, with slight variations in the statistical support for each of the individual sequence datasets. Phylograms obtained by ML are presented for all the individual datasets.

\section{Taxonomy}

Among the 76 strains obtained in this study, five species were identified. Four of these species are new to science, and are described as follows:

Geosmithia jiulianshanensis R. Chang \& X. Zhang, sp. nov. (Fig. 4)

MycoBank MB839256

Page $3 / 22$ 
Etymology: jiulianshanensis, referring to the predominant beetle vector Scolytus jiulianshanensis.

\section{Diagnosis}

The stipe of G. jiulianshanensis is slightly thicker and shorter than that in other species. Geosmithia jiulianshanensis can grow at 5 and $35^{\circ} \mathrm{C}$, even grow slowly at $37^{\circ} \mathrm{C}$.

\section{Type}

CHINA, Jiangxi Province, Ganzhou City, Longnan county, Jiulianshan National Nature Reserve $\left(24^{\circ} 34^{\prime} 11^{\prime \prime} \mathrm{N}, 114^{\circ} 30^{\prime} \mathrm{E}\right)$, from gallery of Scolytus jiulianshanensis on Ulmus sp., 5 May, 2020, S. C. Lai, Y. Xu, S. Liao, Y. Wen \& T. Li (HMAS 249919 - holotype, SNM261 = CGMCC3.20252 - ex-holotype culture).

\section{Description}

Sexual state not observed. Asexual state penicillium-like. Conidiophores borne mostly from aerial fungal hyphae, erect, determinate, solitary, sometimes funiculose, with all parts verrucose; base often consisting of curved and atypically branched cell, stipe (6.4-) 11.3-40.1 (-78.4) $\mu \mathrm{m}$ long, (1.5-) 1.7-3.2 (-6.0) $\mu \mathrm{m}$ wide; penicillus (19.0-) 29.6-61.5 (-85.0) $\mu \mathrm{m}$ long, biverticillate to quaterverticillate (penicilli of conidiophores on aerial funiculose mycelia are monoverticillate or biverticillate), symmetric or asymmetric, often irregularly branched, rami (1st branch) in whorls of X-Y, (4.1-) 5.2-7.0 (-8.7) $\times(1.2-)$ 1.7-2.5 $(-3.2) \mu \mathrm{m}$, metulae (last branch) in whorls of $X-Y,(4.0-) 4.9-6.5$ (-7.6) $\times(1.4-)$ 1.8-2.3 (-2.6) $\mu \mathrm{m}$; phialides in whorls of $X-Y_{\text {, }}$ cylindrical, without or with short cylindrical neck and smooth to verruculose walls, (4.2-)5.1-7.5 (-10.2) $\times(1.1-)$ 1.5-2.3 (-2.7) $\mu \mathrm{m}$. Conidia hyaline to subhyaline, smooth, narrowly cylindrical to ellipsoidal, (2.3-)2.9-4.0 (-4.7) × (0.9-) 1.2-1.7(-2.2) $\mu \mathrm{m}$, produced in non-persistent conidial chains. Substrate conidia absent.

MEA, $8 \mathrm{~d}$ : Colony diam $59-64 \mathrm{~mm}$ at $20^{\circ} \mathrm{C}, 65-78 \mathrm{~mm}$ at $25^{\circ} \mathrm{C}$, and $66-70 \mathrm{~mm}$ at $30^{\circ} \mathrm{C}$. The hyphae grow slowly at 5 and $35^{\circ} \mathrm{C}$. After 8 days of culture, the colony diameter was $1.5-4 \mathrm{~mm}$ and $11-14 \mathrm{~mm}$ respectively. The optimal temperature for growth was $25^{\circ} \mathrm{C}$. Colonies at $25^{\circ} \mathrm{C}, 8 \mathrm{~d}$ were appressed, velutinous or floccose with raised mycelial cords; colony margin smooth, filamentous, diffuse; aerial mycelium sparse; substrate mycelium sparse; conidiogenesis moderate; milky white to light yellow; absence of exudate; no soluble pigment. When incubated at $35{ }^{\circ} \mathrm{C}$, colonies raised, slightly depressed at center, rugose or irregularly furrowed; margin undulate somewhat erose; aerial mycelia sparse to moderate; substratum mycelia dense, forming a tough basal felt; the colony is darker and yellowish brown; soluble pigment is brown. MEA, $37^{\circ} \mathrm{C}, 8 \mathrm{~d}$, germinating only.

Host. Liquidambar formosana, Liquidambar styraciflua, Ulmus sp.

Beetle vectors: Acanthotomicus suncei, Scolytus jiulianshanensis.

\section{Distribution}

Currently only known from Jiangxi and Shanghai

Notes: Geosmithia formosana, G. jiulianshanensis and G. jiangxiensis are phylogenetically close to each other on ITS, TUB2 and TEF1-a trees. The colony morphology of G. formosana, G. jiulianshanensis and G. jiangxiensis are also similar, but there are many differences among those three species. First of all, their sequences are quite different (Table 3). And then, under the microscope, the morphological differences between them are more obvious. The spore of $G$. jiangxiensis is thicker than the other two species. The stipe of $G$. formosana is thinner and longer than other two species, the stipe of $G$. jiangxiensis is obviously thicker than the other two species, and the stipe of $G$. jiulianshanensis is slightly thicker and shorter than that of $G$. formosana. Moreover, their growths at different temperatures are also different (Table 4). Geosmithia formosana cannot grow at 5 and $35^{\circ} \mathrm{C}$ while $\mathrm{G}$. jiulianshanensis can grow at both temperatures, especially at $35^{\circ} \mathrm{C}$, even grow slowly at $37^{\circ} \mathrm{C}$. Geosmithia jiangxiensis only grows a little at $5^{\circ} \mathrm{C}$, and grows slowly at $35^{\circ} \mathrm{C}$. The growth speed of G. jiulianshanensis is faster than other two species (Table 4).

\section{Additional cultures examined}

CHINA, Jiangxi Province, Ganzhou City, Longnan county ( $\left.24^{\circ} 5^{\prime} 2.4^{\prime \prime} \mathrm{N}, 114^{\circ} 47^{\prime} 2.4^{\prime \prime E}\right)$, from gallery of Acanthotomicus suncei on Liquidambar formosana, 5 May, 2020, S. C. Lai (SNM260, SNM246).

CHINA, Jiangxi Province, Ganzhou City, Xunwu county (245'N, 115³8'2"E), from gallery of Acanthotomicus suncei on Liquidambar formosana, 5 May, 2020 (SNM882).

CHINA, Shanghai, from gallery of Acanthotomicus suncei on Liquidambar styraciflua, April 2019, L. Gao (SNM210, SNM226, SNM285, SNM286, SNM287).

Geosmithia jiangxiensis R. Chang \& X. Zhang, sp. nov. (Fig. 5)

MycoBank MB839257

Etymology: jiangxiensis, referring to the place where this species was isolated, Jiangxi Province.

\section{Diagnosis}

The spore and the stipe of G. jiangxiensis is thicker than close related species. Geosmithia jianxiensis only grows a little at 5 and $35^{\circ} \mathrm{C}$.

\section{Type}


CHINA, Jiangxi Province, Ganzhou City, Longnan county $\left(24^{\circ} 5^{\prime} 2.4^{\prime \prime} \mathrm{N}, 114^{\circ} 47^{\prime} 2.4^{\prime \prime E}\right)$, from gallery of Acanthotomicus suncei on Liquidambar formosana, 5 May, 2020, S. C. Lai (HMAS 249920 - holotype, SNM279 = CGMCC3.20253 - ex-holotype culture).

\section{Description}

Sexual state not observed. Asexual state penicillium-like. Conidiophores borne from substrate or aerial hyphae, sometimes arising laterally from another conidiophore, erect, determinate, solitary, with all parts verrucose; stipe commonly (7.3-) 18.4-63.6 (-115.8) $\mu \mathrm{m}$ long, (1.6-) 2.1-3.8 (-5.9) $\mu \mathrm{m}$ wide, penicillus (22.6-) 35.6-85.7 (-119.3) $\mu \mathrm{m}$ long, with walls thick, septate; penicillus terminal, mostly biverticillate, rerely terverticillate, mostly symmetrical, rami (1st branch) in whorls of X-Y, (4.2-) 5.2-7.8 (-10.6) × (1.3-) 2.1-3.5 (-4.8) $\mu \mathrm{m}$; metulae (last branch) in whorls of X-Y, (2.6-) 3.9-5.8 (-7.3) × (1.3-) 1.7-2.6 (-3.3) $\mu \mathrm{m}$. Phialides in whorls of X-Y, (3.9-) 4.6-6.2 (-7.7) $\times(1.5-)$ 1.9-2.8 (-3.9) $\mu \mathrm{m}$, cylindrical, without or with short cylindrical neck and smooth to verruculose walls. Conidia cylindrical to ellipsoidal, smooth, hyaline to subhyaline, (2.2-) 2.5-3.2 (-4.0) × (0.9-) 1.1-1.5 (-1.8) $\mu$ m, formed in non-persistent conidial chains. Substrate conidia absent.

MEA, $8 \mathrm{~d}$ : Colony diam $50-58 \mathrm{~mm}$ at $20^{\circ} \mathrm{C}, 59-69 \mathrm{~mm}$ at $25^{\circ} \mathrm{C}$, and $49-60 \mathrm{~mm}$ at $30^{\circ} \mathrm{C}$. The hyphae grow slowly at 5 and $35^{\circ} \mathrm{C}$. After 8 days of culture, the colony diameter was only $1 \mathrm{~mm}$ and $1-4 \mathrm{~mm}$ respectively. The optimal temperature for growth is $25^{\circ} \mathrm{C}$. Colonies at $25^{\circ} \mathrm{C}, 8 \mathrm{~d}$, plane, slightly raised centrally, velutinous, with slight overgrowth of aerial mycelium, with floccose and funiculose areas; substrate mycelium white, aerial mycelium hyaline; sporulation moderate to heavy, pale cream; vegetative mycelium hyaline; reverse lighter; soluble pigment and exudate absent. When incubated at $35{ }^{\circ} \mathrm{C}$, colonies rising, slightly sunken in the center, furrowed or irregularly fringed; the substratum hyphae was dense and formed a tough basal felt. The colony is dark and yellowish-brown. MEA, $37^{\circ} \mathrm{C}, 8 \mathrm{~d}$ : no growth.

Host. Liquidambar formosana, Ulmus sp.

Beetle vectors: Acanthotomicus suncei, Scolytus jiulianshanensis.

\section{Distribution}

Jiangxi

\section{Notes}

See comparisons between Geosmithia jiulianshanensis, G. jiangxiensis and G. formosana below the description of G. jiulianshanensis.

\section{Additional cultures examined}

CHINA, Jiangxi Province, Ganzhou City, Longnan county, Jiulianshan National Nature Reserve $\left(24^{\circ} 34^{\prime} 11^{\prime \prime} \mathrm{N}, 114^{\circ} 30^{\prime} \mathrm{E}\right)$, from gallery of Scolytus jiulianshanensis on Ulmus sp., 5 May, 2020, S. C. Lai, Y. Xu, S. Liao, Y. Wen \& T. Li(SNM280).

CHINA, Jiangxi Province, Ganzhou City, Xunwu county $\left(24^{\circ} 57^{\prime} \mathrm{N}, 115^{\circ} 38^{\prime} 2^{\prime \prime} \mathrm{E}\right)$, from gallery of Acanthotomicus suncei on Liquidambar formosana, 5 May, 2020 (SNM883, SNM884).

Geosmithia formosana R. Chang \& X. Zhang, sp. nov. (Fig. 6)

MycoBank MB839258

Etymology: formosana, referring to the tree host of Liquidambar formosana where this species has been isolated.

\section{Diagnosis}

The stipe of $G$. formosana is thinner and longer than close related species. Geosmithia formosana cannot grow at 5 and $35^{\circ} \mathrm{C}$.

\section{Type}

CHINA, Jiangxi Province, Ganzhou City, Longnan county $\left(24^{\circ} 5^{\prime} 2.4^{\prime \prime} \mathrm{N}, 114^{\circ} 47^{\prime} 2.4^{\prime \prime E}\right)$, from gallery of Acanthotomicus suncei on Liquidambar formosana, 5 May, 2020, S. C. Lai (HMAS 249921 - holotype, SNM256 = CGMCC3.20254 - ex-holotype culture).

\section{Description}

Sexual state not observed. Asexual state penicillium-like. Conidiophores borne from substrate or aerial mycelium, erect, determinate, solitary, with all parts verrucose; base often consisting of curved and atypically branched cell, stipe (9.2-) 16.7-62.6 (-108.0) × (1.0-) 1.7-3.0 (-3.5) $\mu$ m; penicillus (21.2-) 41.0-88.8 $(-113.9) \mu \mathrm{m}$ long, penicillate conidiophores (penicilli) terminal, biverticillate to quaterverticillate (penicilli of conidiophores on aerial funiculose mycelia are monoverticillate or biverticillate), symmetric or asymmetric, often irregularly branched, rami (1st branch) in whorls of X-Y, (5.1-) 5.7-7.8 (-9.6) $\times(1.3-)$ 1.6-2.5 $(-3.9) \mu \mathrm{m}$, metulae (last branch) in whorls of X-Y, (4.4-)5.1-6.5 (-7.3) $\times(1.1-)$ 1.6-2.4 (-2.9) $\mu \mathrm{m}$; phialides in whorls of X-Y, cylindrical, without or with short cylindrical neck and smooth to verruculose walls, (3.0-)4.7-6.9 (-8.1) × (1.1-) 1.5-2.4 (-3.2) $\mu$ m. Conidia hyaline to subhyaline, smooth, narrowly cylindrical to ellipsoidal, (2.3-)2.7-3.7 (-4.4) × (0.8-) 1.2-1.8(-2.2) $\mu \mathrm{m}$, produced in non-persistent chains. Substrate conidia absent.

MEA, $8 \mathrm{~d}$ : Colony diam $50-54 \mathrm{~mm}$ at $20^{\circ} \mathrm{C}, 58-64 \mathrm{~mm}$ at $25^{\circ} \mathrm{C}$, and $44-52 \mathrm{~mm}$ at $30^{\circ} \mathrm{C}$. The hyphae grow slowly at 5 and $35^{\circ} \mathrm{C}$. After 8 days of culture, the colony diameter was less than $1 \mathrm{~mm}$ and close to $0 \mathrm{~mm}$, respectively. At $35^{\circ} \mathrm{C}$, there was little or no growth. The optimal growth temperature is $25^{\circ} \mathrm{C}$. Colonies 
at $25^{\circ} \mathrm{C}, 8 \mathrm{~d}$, appressed, white velutinous or floccose with raised mycelial cords; colony margin smooth, filamentous, diffuse, pale yellow; aerial mycelium hyaline, sparse; substrate mycelium hyaline, sparse; conidiogenesis moderate; light yellow to brown; absence of exudate; no soluble pigment. MEA, $37^{\circ} \mathrm{C}, 8 \mathrm{~d}$ : no growth.

Host. Liquidambar formosana.

\section{Beetle vectors. Acanthotomicus suncei}

\section{Distribution}

Jiangxi

\section{Notes}

See comparisons between G. jiulianshanensis, G. jiangxiensis and G. formosana below the description of G. jiulianshanensis.

Geosmithia pulverea R. Chang \& X. Zhang, sp. nov. (Fig. 7)

MycoBank MB839259

Etymology: pulverea, powdery in Latin. On MEA medium, G. pulverea has powdery sporulation.

Diagnosis: Geosmithia pulverea produces long spore chain while its close related species does not.

\section{Type}

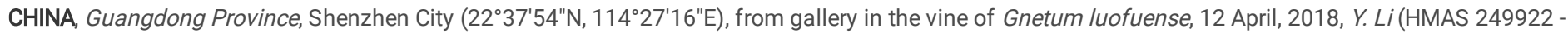
holotype, SNM885 = CGMCC3.20255 - ex-holotype culture).

\section{Description}

Sexual state not observed. Asexual state penicillium-like. Conidiophores arising from substrate or aerial mycelium with all parts verrucose, $40-250$ mm tall; base often consisting of curved and atypically branched cell; stipe (16.2-) 32.7-85.7 (-153.9) × (1.9-) 2.5-3.7 (-4.7) $\mu \mathrm{m}$, penicillus (17.5-) 30.9-84.3 (-120.1) $\mu \mathrm{m}$ long, biverticillate to quaterverticillate, symmetric or asymmetric, often irregularly branched, $2-3 \times$, rarely more, rami (1st branch) in whorls of $X-Y$, (8.2-)

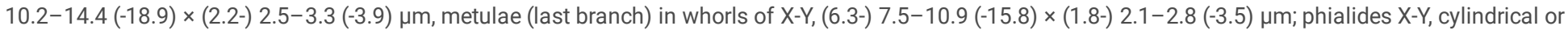
ellipsoidal, without or with short cylindrical neck and smooth to verruculose walls, (5.3-) 7.0-9.6 (-12.3) × (1.5-) 1.8-2.5 (-3.0) $\mu$ m. Conidia hyaline, smooth, narrowly cylindrical to ellipsoidal, (2.1-) 2.5-3.4 (-5.1) × (1.1-) 1.2-1.6 (-2.0) $\mu \mathrm{m}$. Conidia formed in long, non-persistent conidial chains. Substrate conidia absent.

MEA, $8 \mathrm{~d}$ : Colony diam $23-29 \mathrm{~mm}$ at $20^{\circ} \mathrm{C}, 30-37 \mathrm{~mm}$ at $25^{\circ} \mathrm{C}$, and $31-36 \mathrm{~mm}$ at $30^{\circ} \mathrm{C}$. No grow at $5^{\circ} \mathrm{C}$. At $35^{\circ} \mathrm{C}$, mycelia grew slowly. After 8 days of culture, the colony diameter was $1.5-4 \mathrm{~mm}$, with yellow soluble pigment. The optimal growth temperature is $25-30^{\circ} \mathrm{C}$. Colonies at $25^{\circ} \mathrm{C}, 8 \mathrm{~d}$, plane with radial rows and slightly raised centrally, texture velutinous (powdery); sporulation abundant, spore mass Light brownish yellow to buff; reverse yellowish to slightly avellaneous brown; soluble pigment and exudate absent. When incubated at $35^{\circ} \mathrm{C}$, the colonies are the same as above. MEA, $37^{\circ} \mathrm{C}, 8 \mathrm{~d}$ : no growth.

Host. Gnetum luofuense, Liquidambar formosana, L. styraciflua.

Beetle vectors: Acanthotomicus suncei, Crossotarsus emancipatus, Dinoderus sp., Microperus sp.

\section{Distribution}

Gungdong, Guangxi, Hunan, Jiangxi, Shanghai

Notes: Geosmithia pulverea colony was powdery and brown-yellow. One of the most obvious features is the long spore chain. According to the tree made by ITS sequence, SNM888, SNM885 and SNM248 was clustered with Geosmithia sp. 3, and SNM886, SNM887 and SNM270 were clustered with Geosmithia sp. 23 (Fig. 1). However, in the trees with TUB2 and TEF1-a, these strains did not have clear subclassification (Fig. 2 and Fig. 3). It was consequently recognized, using multigene phylogeny, together with Geosmithia sp. 23, as a well-defined phylogenetic species inside the G. pallida species complex (Kolařík et al. 2017; Huang et al. 2017). The colony of G. pulverea was very similar to Geosmithia sp. 3 on MEA, but Geosmithia sp. 3 was darker and wrinkled (Kolařík et al. 2004). Geosmithia pulverea seems to have smaller stipe size, but other features fit to the morphology of Geosmithia sp. 3 (Kolařík et al. 2004). In this study, we are providing a formal description for the Chinese strains related to Geosmithia sp. 3 and sp. 23 which are known to be distributed over various bark beetle hosts in the Temperate Europe in case of Geosmithia sp. 3 (Kolařík et al. 2004, 2008; Strzałka et al. 2021) or seems to have global distribution and many bark beetle hosts across Temperate Europe (Strzalka et al. 2021), Mediterranean basin (Kolařík et al. 2007), Northern America (Kolařík et al. 2017; Huang et al. 2017, 2019) and Seychelles (Kolařík et al. 2017). The further study is needed to assess the taxonomic relationships between G. pulverea, Geosmithia sp. 3 and Geosmithia sp. 23.

Additional cultures examined: CHINA, Guangxi Province, Shangsi City $\left(21^{\circ} 54^{\prime} 12^{\prime \prime} \mathrm{N}, 107^{\circ} 54^{\prime} 14^{\prime \prime} \mathrm{E}\right)$, from body surface of Crossotarsus emancipates, $27 \mathrm{March}$, 2018, Y. Li (SNM887, SNM886). 
CHINA, Hunan Province, Changsha City $\left(28^{\circ} 10^{\prime} 56^{\prime \prime} \mathrm{N}, 112^{\circ} 55^{\prime} 41^{\prime \prime E}\right)$, from gallery of Microperus sp. L589, 15 July, 2019, Y. Li (SNM888).

CHINA, Jiangxi Province, Ganzhou City, Longnan county $\left(24^{\circ} 5^{\prime} 2.4^{\prime \prime} \mathrm{N}, 114^{\circ} 47^{\prime} 2.4^{\prime \prime E}\right)$, from gallery of Acanthotomicus suncei on Liquidambar formosana, 5 May, 2020, S. C. Lai (SNM270).

CHINA, Shanghai, from gallery of Acanthotomicus suncei on Liquidambar styraciflua, April 2019, L. Gao (SNM248).

\section{Discussion}

A total of 76 strains of Geosmithia were isolated in this study. Analyses of ITS, TUB2 and TEF1-a showed those isolates were separated into five taxa, with one of these strains has been named in previous, G. putterillii, and the other four were novel species, described as $G$. jiulianshanensis, G. jiangxiensis, $G$. formosana and G. pulverea in this study. Those species were isolated from larvae, frass and wood dust in beetle galleries of dying, stressed or weakened broad-leaf tree host, such as Liquidambar spp. and Ulmus sp.

The dominant species obtained in this study were G. jiulianshanensis and G. pulverea, with 38 and 18 strains respectively (Table 1). The reason for their abundance in our dataset is the fact that our study focused on sampling from Altinginaceae; it does not mean that the fungus is dominant in other tree taxa. Four species, G. putterillii, G. jiangxiensis and G. formosana have only been isolated in Jiangxi (Table 1). The samples collected from Guangdong, Guangxi and Hunan only yielded G. pulverea.

Geosmithia putterillii was isolated from bark beetles feeding on plants from the family of Rossaceae (Kolařík et al. 2008) and Lauraceae in Europe (Kolařík et al. 2004) and on various families of Angiosperms and Gymnosperms in the Western U.S. (Kolařik et al. 2017). The type strain was isolated from the timber in the New Zealand (Pitt 1979). In this study, G. putterillii was isolated from gallery of Phloeosinus sp. on Lauraceae sp. log (Jiangxi). This study is the first report of $G$. putterillii in China. It is becoming clear that G. putterillii is widely distributed globally, across many beetle hosts.

Most of G. jiulianshanensis were isolated from the galleries of $A$. suncei (Table 1). Acanthotomicus suncei was recorded on Liquidambar in Fujian, Jiangsu, Jiangxi, Zhejiang, and Shanghai, China (Li et al. 2021). The hosts of this beetle were limited to sweet gum trees, such as $L$. styraciflua and $L$. formosana. The beetle was recorded as an agent of great damage to the imported American sweetgum L. styraciflua in Shanghai and neighbouring Jiangsu province (Gao and Cognato 2018). The role of the fungus in this outbreak and in the tree pathology remains uninvestigated, though the authors of this paper noted small lesions around the beetle galleries. The other five isolates were isolated from the galleries of Scolytus jiulianshanensis on UImus sp, which suggests that G. jiulianshanensis might colonize wide range tree hosts.

Geosmithia jiangxiensis was only isolated in samples from Jiangxi province, from two plant families: Altinginaceae and Ulmaceae (Table 1). The colony of G. jiangxiensis is similar to G. jiulianshanensis in morphology, but the difference can be seen in the growth rate and micromorphology.

Geosmithia pulverea, is a species closely related to Geosmithia sp. 3 and Geosmithia sp. 23 which are know from various bark beetle hosts in Europa, USA and Seychelles (Kolařík et al. 2007, 2008, 2017; Huang et al. 2017, 2019), and further study need to clarify among these three lineages. In this study, we isolated G. pulverea from A. gracilipes, Gne. Iuofuense, L. formosana and Ulmus sp. (Table 1), which suggested that this species could colonize a very wide variety of plant hosts. It is also the most widely distributed species, isolated from Guangdong, Guangxi, Hunan, Jiangxi, and Shanghai (Table 1) and vectored by several beetle species, such as, S. jiulianshanensis, A. suncei, C. emancipatus, Dinoderus sp. Microperus sp. and Phloeosinus sp. (Table 1). Moreover, the abundant of Geosmithia species associated with Acanthotomicus suncei in the current study was also consistent with the frequent occurrence in Shanghai and Jiangxi (Gao et al. 2021).

\section{Conclusions}

This study does not provide sufficient data to determine the structure of the Geosmithia community in southern China, as was inferred in Europe and USA after a significantly greater sampling effort (Kolařík et al. 2007, 2008, 2013, 2017; Huang et al. 2017, 2019; Jankowiak et al. 2014). Fungal communities are regulated by a number of factors, including geographic location, host tree species and bark beetle vectors, and further sampling is needed to understand the determinants (Veselská et al. 2019). It is clear, however, that the diversity of China's subcortical fungi is substantial. Fungal communities associated with trees need to be further investigated because many currently unknown species may cause plant diseases.

\section{Abbreviations}

BI: Bayesian inference; ITS: Nuclear ribosomal internal transcribed spacer; TEF1-a: Translation elongation factor 1-a; TUB2: $\beta$-tubulin ; ML: Maximum likelihood; PCR: Polymerase chain reaction; CGMCC: China General Microbiological Culture Collection Center; HMAS: Herbarium Mycologicum, Academiae Sinicae; TCD: Thousand cankers disease

\section{Declarations}

\section{Acknowledgements}

We would like to thank Ling Zhang, Shengchang Lai (Jiangxi Agricultural University), Dr. Yongying Ruan (Shenzhen Polytechnic) and Dr. Lei Gao (Shanghai Academy of Landscape Architecture Science and Planning) for assisting the insect collection, Dr. Sarah Smith and Prof. Anthony Cognato (Michigan State University) for assisting with beetle identification. Dr. Shuping Wang (Shanghai Entry-Exit Inspection and Quarantine Bureau) and Jue Wang (Beijing Forest 
University) for assisting with sequencing. You Li and Jiri Hulcr were partially funded by a cooperative agreement with the USDA Forest Service, by the USDA APHIS Plant Protection Act, and by the National Science Foundation. This publication may not necessarily express APHIS's views.

\section{Adherence to national and international regulations}

Not applicable.

\section{Authors' contributions}

Runlei Chang Meixue Dai and You Li designed the research. You Li, Hongli Si and Gouyan Zhao collected samples. Xiuyu Zhang, Runlei Chang and You Li isolated and purified fungal cultures. Xiuyu Zhang, Runlei Chang and Xiaoqian Jiang completed the data acquisition, analyses and interpretation. Xiuyu Zhang and Runlei Chang completed the writing of the paper. Miroslav Kolařík, Jiri Hulcr and You Li revised text, taxonomy and phylogeny. All authors approved the manuscript.

\section{Availability of data and materials}

The datasets generated for this study (Table 2) can be accessed via GenBank: https://www.ncbi.nlm.nih.gov/genbank/. Alignments used during the current study are available at TreeBase:https://www.treebase.org/.

\section{Ethics approval and consent to participate}

Not applicable.

\section{Consent for publication}

Not applicable.

\section{Competing interests}

The authors declare that they have no competing interests.

\section{References}

1. Crous PW, Luangsa-Ard JJ, Wingfield MJ, Carnegie AJ, Hernández-Restrepo M, Lombard L, Roux J, Barreto RW, Baseia IG, Cano-Lira JF, Martín MP, Morozova OV, Stchigel AM, Summerell BA, Brandrud TE, Dima B, García D, Giraldo A, Guarro J, Gusmão LFP, Khamsuntorn P, Noordeloos ME, Nuankaew S, Pinruan U, Rodríguez-Andrade E, Souza-Motta CM, Thangavel R, van Iperen AL, Abreu VP, Accioly T, Alves JL, Andrade JP, Bahram M, Baral HO, Barbier E, Barnes CW, Bendiksen E, Bernard E, Bezerra JDP, Bezerra JL, Bizio E, Blair JE, Bulyonkova TM, Cabral TS, Caiafa MV, Cantillo T, Colmán AA, Conceição LB, Cruz S, Cunha AOB, Darveaux BA, da Silva AL, da Silva GA, da Silva GM, da Silva RMF, de Oliveira RJV, Oliveira RL, De Souza JT, Dueñas M, Evans HC, Epifani F, Felipe MTC, Fernández-López J, Ferreira BW, Figueiredo CN, Filippova NV, Flores JA, Gené J, Ghorbani G, Gibertoni TB, Glushakova AM, Healy R, Huhndorf SM, Iturrieta-González I, Javan-Nikkhah M, Juciano RF, Jurjević Ž, Kachalkin AV, Keochanpheng K, Krisai-Greilhuber I, Li YC, Lima AA, Machado AR, Madrid H, Magalhães OMC, Marbach PAS, Melanda GCS, Miller AN, Mongkolsamrit S, Nascimento RP, Oliveira TGL, Ordoñez ME, Orzes R, Palma MA, Pearce CJ, Pereira OL, Perrone G, Peterson SW, Pham THG, Piontelli E, Pordel A, Quijada L, Raja HA, Rosas de Paz E, Ryvarden L, Saitta A, Salcedo SS, Sandoval-Denis M, Santos TAB, Seifert KA, Silva BDB, Smith ME, Soares AM, Sommai S, Sousa JO, Suetrong S, Susca A, Tedersoo L, Telleria MT, Thanakitpipattana D, Valenzuela-Lopez N, Visagie CM, Zapata M, Groenewald JZ (2018) Fungal Planet description sheets: 785-867. Persoonia 41: 238417

2. Darriba D, Taboada GL, Doallo R, Posada D (2012) jModelTest 2: more models, new heuristics and parallel computing. Nat Methods 9:772-772

3. Gao L, Cognato Al (2018) Acanthotomicus suncei, a new sweetgum tree pest in China (Coleoptera: Curculionidae: Scolytinae: Ipini). Zootaxa 4471:595599

4. Gao L, Li Y, Wang ZX, Zhao J, Hulcr J, Wang JG, Li YZ, Ju RT (2021) Biology and associated fungi of an emerging bark beetle pest, the sweetgum inscriber Acanthotomicus suncei (Coleoptera: Curculionidae). J Appl Entomol dol. 10.1111/jen.12861

5. Gardes M, Bruns TD (1993) ITS primers with enhanced specificity for basidiomycetes - application to the identification of mycorrhizae and rusts. Mol Ecol $2: 113-118$

6. Glass NL, Donaldson GC (1995) Development of primer sets designed for use with the PCR to amplify conserved genes from filamentous Ascomycetes. Appl Environ Microb 61:1323

7. Hishinuma SM, Dallara PL, Yaghmour MA, Zerillo MM, Parker CM, Roubtsova TV, Nguyen TL, Tisserat NA, Bostock RM, Flint ML et al (2015) Wingnut (Juglandaceae) as a new generic host for Pityophthorus juglandis(Coleoptera: Curculionidae) and the thousand cankers disease pathogen, Geosmithia morbida(Ascomycota: Hypocreales). The Can Entomol 148:83-91

8. Huang Y-T, Skelton J, Johnson AJ, Kolařík M, Hulcr J (2019) Geosmithia species in southeastern USA and their affinity to beetle vectors and tree hosts. Fungal Ecol 39:168-183

9. Huang YT, Kolarik M, Kasson MT, Hulcr J (2017) Two new Geosmithia species in G. pallida species complex from bark beetles in eastern USA. Mycologia 109:790-803

10. Jankowiak R, Kolařík M, Bilański P (2014) Association of Geosmithia fungi (Ascomycota: Hypocreales) with pine- and spruce-infesting bark beetles in Poland. Fungal Ecol 11:71-79 
11. Jankowiak R, Strzałka B, Bilański P, Linnakoski R, Aas T, Solheim H, Groszek M, de Beer ZW (2017) Two new Leptographium spp. reveal an emerging complex of hardwood-infecting species in the Ophiostomatales. Anton Leeuw Int J G 110:1537-1553

12. Jankowiak R, Kolarik M (2010) Fungi associated with the fir bark beetle Cryphalus piceae in Poland. Forest Pathol 40:133-144

13. Juzwik J, Banik MT, Reed SE, English JT, Ginzel MD (2015) Geosmithia morbida Found on Weevil Species Stenomimus pallidus in Indiana. Plant Health Pro 16:7-10

14. Katoh K, Standley DM (2013) MAFFT Multiple Sequence Alignment Software Version 7: Improvements in Performance and Usability. Mol Biol Evol $30: 772-780$

15. Kirschner R (2001) Diversity of filamentous fungi in bark beetle galleries incentral Europe. In: Misra JK, Horn BW (eds) Trichomycetesand Other Fungal Groups. Trichomycetes and Other Fungal Groups. Robert W Lichtwardt Commemoration Volume, Robert W, pp 175-196

16. Kolařík M, Freeland E, Utley C, Tisserat N (2011) Geosmithia morbida sp. nov., a new phytopathogenic species living in symbiosis with the walnut twig beetle (Pityophthorus juglandis) on Juglans in USA. Mycologia 103:325-332

17. Kolařík M, Hulcr J, Tisserat N, De Beer W, Kostovcik M, Kolarikova Z, Seybold SJ, Rizzo DM (2017) Geosmithia associated with bark beetles and woodborers in the western USA: taxonomic diversity and vector specificity. Mycologia 109:185-199

18. Kolařík M, Jankowiak R (2013) Vector affinity and diversity of Geosmithia fungi living on subcortical insects inhabiting Pinaceae species in central and northeastern Europe. Microb Ecol 66:682-700

19. Kolařík M, Kirkendall LR (2010) Evidence for a new lineage of primary ambrosia fungi in Geosmithia Pitt (Ascomycota: Hypocreales). Fungal Biol 114:676-689

20. Kolařik M, Kostovcik M, Pazoutova S (2007) Host range and diversity of the genus Geosmithia (Ascomycota: Hypocreales) living in association with bark beetles in the Mediterranean area. Mycol Res 111:1298-1310

21. Kolařík M, Kuba'tova Á, Cepicka I, Pazoutova S, S`rutka P (2005) A complex of three new white-spored, sympatric, and host range limited Geosmithia species. Mycol Res 109:1323-1336

22. Kolařík M, Kubatova A, Hulcr J, Pazoutova S (2008) Geosmithia fungi are highly diverse and consistent bark beetle associates: evidence from their community structure in temperate Europe. Microb Ecol 55:65-80

23. Kolarík M, Kubátová A, Pažoutová S, Šrûtka P (2004) Morphological and molecular characterisation of Geosmithia putterillii, G. pallida comb. nov. and G. flava sp. nov., associated with subcorticolous insects. Mycol Res 108:1053-1069

24. Kubátová A, Kolařík M, Prášil K, Novotný D (2004) Bark beetles and their galleries: well-known niches for little known fungi on the example of Geosmithia. Czech Mycol 56:1-18

25. Lin YT, Shih HH, Huang YT, Lin CS, Chen CY (2016) Two species of beetle-associated Geosmithia in Taiwan. Fung Sci 31:29-36

26. Li Y, Wan Y, Lin W, Ernstsons AS, Gao L (2021) Estimating Potential Distribution of Sweetgum Pest Acanthotomicus suncei and Potential Economic Losses in Nursery Stock and Urban Areas in China. Insects 155. doi: https://doi.org/10.3390/insects12020155

27. Lynch SC, Wang DH, Mayorquin JS, Rugman-Jones PF, Stouthamer R, Eskalen A (2014) First report of Geosmithia pallida causing Foamy Bark Canker, a new disease on Coast Live Oak (Quercus agrifolia), in association with Pseudopityophthorus pubipennis in California. Plant Dis $98: 1276$

28. Machingambi NM, Roux J, Dreyer LL, Roets F (2014) Bark and ambrosia beetles (Curculionidae: Scolytinae), their phoretic mites (Acari) and associated Geosmithia species (Ascomycota: Hypocreales) from Virgilia trees in South Africa. Fungal Biol 118:472-483

29. McPherson BA, Erbilgin N, Bonello P, Wood DL (2013) Fungal species assemblages associated with Phytophthora ramorum-infected coast live oaks following bark and ambrosia beetle colonization in northern California. Forest Ecol Manag 291:30-42

30. Miller AN, Pfeiffer W, Schwartz T (2010) Creating the CIPRES Science Gateway for Inference of Large Phylogenetic Trees. In: Gateway computing environments workshop. GCE) IEEE, New Orleans, pp 1-8

31. Montecchio L, Fanchin G, Simonato M, Faccoli M (2014) First Record of Thousand Cankers Disease Fungal Pathogen Geosmithia morbida and Walnut Twig Beetle Pityophthorus juglandis on Juglans regia in Europe. Plant Dis 98:1445-1445

32. O'Donnell K, Cigelnik E (1997) Two Divergent Intragenomic rDNA ITS2 Types within a Monophyletic Lineage of the Fungus Fusarium Are Nonorthologous. Mol Phylogenet Evol 7:103-116

33. Pepori AL, Kolarik M, Bettini PP, Vettraino AM, Santini A (2015) Morphological and molecular characterisation of Geosmithia species on European elms. Fungal Biol 119:1063-1074

34. Pitt J (1979) Geosmithia gen. nov. for Penicillium lavendulum and related species. Can J of Bot 57:2021-2030

35. Pitt J, Hocking A (2012) Fungi and food spoilage. Springer, New York, 519 p

36. Rehner SA, Buckley E (2005) A Beauveria phylogeny inferred from nuclear ITS and EF1-a sequences: evidence for cryptic diversification and links to Cordyceps teleomorphs. Mycologia 97:84-98

37. Ronquist F, Teslenko M, van der Mark P, Ayres DL, Darling A, Höhna S, Larget B, Liu L, Suchard MA, Huelsenbeck JP (2012) MrBayes 3.2: Efficient Bayesian Phylogenetic Inference and Model Choice Across a Large Model Space. Syst Biol 61:539-542

38. Skelton J, Jusino MA, Li Y, Bateman C, Thai PH, Lindner DL, Hulcr J (2018) Detecting symbioses in complex communities: the specialist and generalist fungal symbionts of beetles within dead Asian pines. Microb Ecol 76(3):839-850

39. Seifert KA, De Beer ZW, Wingfield MJ (2013) Ophiostomatoid fungi: expanding frontiers. Utrecht, Netherlands

40. Seybold SJ, Haugen D, O’Brien J, Graves AD (2013) Thousand Cankers Disease. USDA Forest Service, Northeastern Area State and Private Forestry Pest Alert. NA-PR-02e10, originally published May 2010

Page $9 / 22$ 
41. Six DL, Bentz BJ (2007) Temperature determines symbiont abundance in a multipartite bark beetle-fungus ectosymbiosis. Microb Ecol 54:112-118

42. Six DL, Wingfield MJ (2010) The Role of Phytopathogenicity in Bark Beetle-Fungus Symbioses: A Challenge to the Classic Paradigm. Annu Rev Entomol $56: 255-272$

43. Stamatakis A (2014) RAxML version 8: a tool for phylogenetic analysis and post-analysis of large phylogenies. Bioinformatics 30:1312-1313

44. Stodůlková E, Kolařík M, Křesinová Z, Kuzma M, Šulc M, Man P, Novák P, Maršík P, Landa P, Olšovská J et al (2009) Hydroxylated anthraquinones produced by Geosmithia species. Folia Microbiol 54:179-187

45. Strzalka B, Kolarik M, Jankowiak R (2021) Geosmithia associated with hardwood-infesting bark and ambrosia beetles, with the description of three new species from Poland. Antonie Van Leeuwenhoek

46. Tisserat N, Cranshaw W, Leatherman D, Utley C, Alexander K (2009) Black Walnut Mortality in Colorado Caused by the Walnut Twig Beetle and Thousand Cankers Disease. Plant Health Pro 10

47. Tisserat N, Cranshaw W, Putnam ML, Pscheidt J, Leslie CA, Murray M, Hoffman J, Barkley Y, Alexander K, Seybold SJ (2011) Thousand Cankers Disease is Widespread in Black Walnut in the Western United States. Plant Health Pro 12

48. Utley C, Nguyen T, Roubtsova T, Coggeshall M, Ford TM, Grauke LJ, Graves AD, Lesile ChA, McKenna J, Woeste K, Yaghmour MA, Seybold SJ, Bostock RM, Tisserat N (2013) Susceptibility of walnut and hickory species to Geosmithia morbida. Plant Dis 97:601-607

49. Veselská T, Skelton J, Hulcr J, Chudíčková M, Vojtová T, Kostovck M, Cajthaml T, Baldrian P (2019) Adaptive traits of bark and ambrosia beetle-associated fungi. Fungal Ecol 41:165-176

50. White TJ, Bruns T, Lee S, Taylor J (1990) Amplification and direct sequencing of fungal ribosomal RNA genes for phylogenetics. In: Innis MA, Gelfand DH, Sninsky JJ, White TJ (eds) PCR Protocols: A Guide to the Methods and Applications, 18. Academic Press, New York, pp 315-322

\section{Tables}

Table 1 Distribution and number of species of Geosmithia among 76 isolated strains

\begin{tabular}{|c|c|c|c|c|}
\hline Geosmithia specie & Location & Tree host & Beetle species & Number(76) \\
\hline G. formosana (1) & Jiangxi & Liquidambar formosana & Acanthotomicus suncei & 1 \\
\hline \multirow[t]{3}{*}{ G. jiangxiensis (14) } & Jiangxi & Liquidambar formosana & Acanthotomicus suncei & 7 \\
\hline & & Ulmus sp. & Scolytus jiulianshanensis & 1 \\
\hline & & Altingia gracilipes & Acanthotomicus suncei & 6 \\
\hline \multirow[t]{3}{*}{ G. jiulianshanensis (38) } & Jiangxi & Liquidambar formosana & Acanthotomicus suncei & 25 \\
\hline & & Ulmus sp. & Scolytus jiulianshanensis & 5 \\
\hline & Shanghai & Liquidambar styraciflua & Acanthotomicus suncei & 8 \\
\hline \multirow[t]{7}{*}{ G. pulverea (18) } & Guangdong & Gnetum luofuense & Dinoderus sp. & 1 \\
\hline & Guangxi & unknown & Crossotarsus emancipatus & 2 \\
\hline & Hunan & unknown & Microperus sp. & 1 \\
\hline & Jiangxi & Liquidambar formosana & Acanthotomicus suncei & 1 \\
\hline & & unknown & Phloeosinus sp. & 6 \\
\hline & & Ulmus sp. & Scolytus jiulianshanensis & 1 \\
\hline & & Altingia gracilipes & Acanthotomicus suncei & 4 \\
\hline \multirow[t]{2}{*}{ G. putterillii (6) } & Jiangxi & Lauraceae & Phloeosinus sp. & 6 \\
\hline & Shanghai & Liquidambar styraciflua & Acanthotomicus suncei & 1 \\
\hline
\end{tabular}

Table 2 Cultures examined in this study and their GenBank accession numbers 


\begin{tabular}{|c|c|c|c|c|c|c|c|}
\hline \multirow[b]{2}{*}{ Species } & \multirow[b]{2}{*}{ Isolation no } & \multirow[b]{2}{*}{ Beetle vectors } & \multirow[b]{2}{*}{ Tree host } & \multirow[b]{2}{*}{ ITS } & \multicolumn{2}{|c|}{ GenBank accession no } & \multirow[b]{2}{*}{ Referen } \\
\hline & & & & & TEF1- $a$ & TUB2 & \\
\hline \multirow[t]{3}{*}{ G. brunnea } & CBS 142634 & $\begin{array}{l}\text { Xylosandrus } \\
\text { compactus }\end{array}$ & $\begin{array}{l}\text { Liquidambar } \\
\text { styraciflua }\end{array}$ & KY872741 & KY872746 & KY872751 & $\begin{array}{l}\text { Present } \\
\text { study }\end{array}$ \\
\hline & CBS 142635 & X. compactus & L. styraciflua & KY872742 & KY872747 & KY872752 & $\begin{array}{l}\text { Present } \\
\text { study }\end{array}$ \\
\hline & CBS $142633^{\top}$ & $\begin{array}{l}\text { Hypothenemus } \\
\text { dissimilis }\end{array}$ & Quercussp. & KY872743 & KY872748 & KY872753 & $\begin{array}{l}\text { Present } \\
\text { study }\end{array}$ \\
\hline \multirow[t]{2}{*}{ G. cnesini } & CCF 3753 & Cnesinus lecontei & Croton draco & AM947670 & & & $\begin{array}{l}\text { Kolařík } \\
\text { al. (201 }\end{array}$ \\
\hline & MK 1820 & C. lecontei & C. draco & AM947671 & & & $\begin{array}{l}\text { Kolaríík } \\
\text { al. (201 }\end{array}$ \\
\hline \multirow[t]{2}{*}{ G. eupagioceri } & MKA1-b & $\begin{array}{l}\text { Eupagiocerus } \\
\text { dentipes }\end{array}$ & Paullinia renesii & AM947666 & & & $\begin{array}{l}\text { Kolarík } \\
\text { al. (201 }\end{array}$ \\
\hline & CCF 3754 & & & & LR535705 & & $\begin{array}{l}\text { Kolarík } \\
\text { al. }(201\end{array}$ \\
\hline \multirow[t]{3}{*}{ G. fagi } & CCF 6235 & Taphrorychus bicolor & Fagus sy/vatica & LR812775 & LR813193 & LR813119 & $\begin{array}{l}\text { Strzalk: } \\
\text { al. 2027 }\end{array}$ \\
\hline & 21114TBb & T. bicolor & F. sylvatica & LR812776 & & LR813120 & $\begin{array}{l}\text { Strzalk: } \\
\text { al. 202" }\end{array}$ \\
\hline & $\operatorname{CCF} 6234^{\top}$ & T. bicolor & F. sylvatica & LR812785 & LR813141 & LR813129 & $\begin{array}{l}\text { Strzalk: } \\
\text { al. 202 }\end{array}$ \\
\hline \multirow[t]{4}{*}{ G. fassatiae } & AK $31 / 98$ & S. intricatus & Quercus sp. & AM421039 & MH580557 & & $\begin{array}{l}\text { Kolarík } \\
\text { al. (200 }\end{array}$ \\
\hline & CCF 4331 & & & HF546239 & & KF853894 & $\begin{array}{l}\text { Kolařík } \\
\text { al. (201 }\end{array}$ \\
\hline & CCF 4340 & & & HF546247 & & KF853895 & $\begin{array}{l}\text { Kolařík } \\
\text { al. (201 }\end{array}$ \\
\hline & CCF $3334^{\top}$ & & $\begin{array}{l}\text { Quercus } \\
\text { pubescens }\end{array}$ & & MH580530 & & $\begin{array}{l}\text { Kolaríík } \\
\text { al. }(200\end{array}$ \\
\hline \multirow[t]{2}{*}{ G. flava } & CCF $3333^{\top}$ & Xiphydria sp. & Castanea sativa & AJ578483 & MH580541 & & $\begin{array}{l}\text { Kolařík } \\
\text { al. }(200\end{array}$ \\
\hline & CCF4337 & Cerambycidae sp. & $\begin{array}{l}\text { Pseudotsuga } \\
\text { menziesii }\end{array}$ & HF546244 & MH580542 & KF853897 & $\begin{array}{l}\text { Kolařík } \\
\text { al. }(200\end{array}$ \\
\hline \multirow[t]{2}{*}{ G. formosana } & SNM256= & A. suncei & L. formosana & MW222401 & MW592423 & MW592403 & \\
\hline & CGMCC3.20254 & & & & & & \\
\hline \multirow[t]{5}{*}{ G. jiangxiensis } & SNM279= & A. suncei & L. formosana & MW222397 & MW592420 & MW592402 & \\
\hline & CGMCC3.20253 & & & & & & \\
\hline & SNM280 & S. jiulianshanensis & Ulmus sp. & MW222396 & MW592409 & MW592401 & \\
\hline & SNM883 & A. suncei & L. formosana & MW222407 & MW592412 & MW592399 & \\
\hline & SNM884 & A. suncei & L. formosana & MW222406 & MW592411 & MW592400 & \\
\hline \multirow{10}{*}{ jiulianshanensis } & SNM261= & S. jiulianshanensis & Ulmus sp. & MW222399 & MW592410 & MW592395 & \\
\hline & CGMCC3.20252 & & & & & & \\
\hline & SNM246 & $\begin{array}{l}\text { Acanthotomicus } \\
\text { suncei }\end{array}$ & $\begin{array}{l}\text { Liquidambar } \\
\text { formosana }\end{array}$ & MW222403 & MW592425 & MW592393 & \\
\hline & SNM260 & A. suncei & L. formosana & MW222400 & MW592422 & MW592394 & \\
\hline & SNM226 & A. suncei & L. styraciflua & MW222404 & MW592426 & MW592392 & \\
\hline & SNM210 & A. suncei & L. styraciflua & MW222405 & MW592427 & MW592391 & \\
\hline & SNM285 & A. suncei & L. styraciflua & MW222395 & MW592408 & MW592396 & \\
\hline & SNM286 & A. suncei & L. styraciflua & MW222394 & MW592407 & MW592397 & \\
\hline & SNM287 & A. suncei & L. styraciflua & MW222393 & MW592406 & MW592398 & \\
\hline & SNM882 & A. suncei & L. formosana & MW222408 & MW592413 & MW592390 & \\
\hline G. lavendula & CCF 3051 & & Laboratory & AF033385 & & & Kolařík \\
\hline
\end{tabular}


CCF 3394

CCF 4336

KF853902

\begin{tabular}{|c|c|c|c|c|c|c|c|}
\hline G. langdonii & CCF $3332^{\top}$ & Scolytus intricatus & Quercus robur & KF808297 & HG799876 & HG799887 & $\begin{array}{l}\text { Kolařík } \\
\text { al. (200 } \\
2017)\end{array}$ \\
\hline & CCF 4338 & Cryphalus pubescens & $\begin{array}{l}\text { Sequoia } \\
\text { serpervirens }\end{array}$ & HF546245 & HG799877 & HG799881 & $\begin{array}{l}\text { Kolařík } \\
\text { al. (201 }\end{array}$ \\
\hline \multirow[t]{2}{*}{ G. longistipitata } & RJ278m & $\begin{array}{l}\text { Pityophthorus } \\
\text { pityographus }\end{array}$ & Picea abies & HE604124 & & & $\begin{array}{l}\text { Strzalki } \\
\text { al. 2021 }\end{array}$ \\
\hline & $\operatorname{CCF} 4210^{\top}$ & P. pityographus & P. abies & HE604154 & LR813194 & LR813140 & $\begin{array}{l}\text { Strzalki } \\
\text { al. 2021 }\end{array}$ \\
\hline G. microcorthyli & $\operatorname{CCF} 3861^{\top}$ & Microcorthylus sp. & Cassia grandis & FM986798 & MH580560 & FM986793 & $\begin{array}{l}\text { Kolařík } \\
\text { Kirkend } \\
(2010)\end{array}$ \\
\hline \multirow[t]{3}{*}{ G. morbida } & CBS 124664 & & Juglans nigra & FN434081 & & KF853912 & $\begin{array}{l}\text { Kolařík } \\
\text { al. (201 }\end{array}$ \\
\hline & CCF 3881 & $\begin{array}{l}\text { Pityophthorus } \\
\text { juglandis }\end{array}$ & J. nigra & FN434082 & MH580543 & KF853911 & $\begin{array}{l}\text { Kolařík } \\
\text { al. (201 }\end{array}$ \\
\hline & CCF 4576 & P. juglandis & J. nigra & & MH580544 & & $\begin{array}{l}\text { Kolařík } \\
\text { al. (200 }\end{array}$ \\
\hline \multirow[t]{2}{*}{ G. obscura } & CCF $3422^{\top}$ & S. intricatus & Q. robur & AJ784999 & MH580539 & & $\begin{array}{l}\text { Kolařík } \\
\text { al. (200 }\end{array}$ \\
\hline & CCF 3425 & S. carpini & Carpinus betulus & AM181460 & MH580540 & KF853914 & $\begin{array}{l}\text { Kolařík } \\
\text { al. (200 }\end{array}$ \\
\hline \multirow[t]{5}{*}{ G. omnicola10 } & MK 1707 & Hylesinus orni & Fraxinus sp. & AM181452 & MH580558 & & $\begin{array}{l}\text { Kolařík } \\
\text { al. (200 }\end{array}$ \\
\hline & CNR115 & & Ulmus minor & & & KP990607 & $\begin{array}{l}\text { Pepori, } \\
\text { et al. } \\
\text { (2015) }\end{array}$ \\
\hline & CNR5 & & Ulmus glabra & & & KP990546 & $\begin{array}{l}\text { Pepori, } \\
\text { et al. } \\
\text { (2015) }\end{array}$ \\
\hline & IMI 194089 & H. orni & Fraxinus sp. & AM181450 & & & $\begin{array}{l}\text { Kolařík } \\
\text { al. (200 }\end{array}$ \\
\hline & CCF 3553 & H. orni & Fraxinus sp. & AM181433 & & & $\begin{array}{l}\text { Kolařík } \\
\text { al. (200 }\end{array}$ \\
\hline \multirow[t]{2}{*}{ G. pallida } & CCF $3053^{\top}$ & & Cotton yarn & AJ578486 & & HG799817 & $\begin{array}{l}\text { Kolařrík } \\
\text { al. (200 } \\
2017)\end{array}$ \\
\hline & CCF 3324 & & Soil & & HG799846 & HG799809 & $\begin{array}{l}\text { Kolařŕk } \\
\text { al. (200 } \\
2017)\end{array}$ \\
\hline \multirow[t]{5}{*}{ G. pazoutovae } & 22015aSI & S. intricatus & Q. robur & LR812786 & & LR813130 & $\begin{array}{l}\text { Strzalki } \\
\text { al. 2021 }\end{array}$ \\
\hline & 24Wa14SI & S. intricatus & Q. robur & LR812787 & & LR813131 & $\begin{array}{l}\text { Strzalki } \\
\text { al. 2021 }\end{array}$ \\
\hline & CCF $6233^{\top}$ & S. intricatus & Q. robur & LR812796 & LR813142 & LR813138 & $\begin{array}{l}\text { Strzalki } \\
\text { al. 2021 }\end{array}$ \\
\hline & CBS $142636^{\top}$ & $\begin{array}{l}\text { Phloeotribus } \\
\text { frontalis }\end{array}$ & Acer negundo & KY872744 & KY872749 & KY872754 & $\begin{array}{l}\text { Present } \\
\text { study }\end{array}$ \\
\hline & CBS 142637 & P. frontalis & A. negundo & KY872745 & KY872750 & KY872755 & $\begin{array}{l}\text { Present } \\
\text { study }\end{array}$ \\
\hline G. pulverea & SNM885= & Dinoderus sp. & $\begin{array}{l}\text { Gnetum } \\
\text { luofuense }\end{array}$ & MW222410 & MW592415 & MW592388 & \\
\hline
\end{tabular}




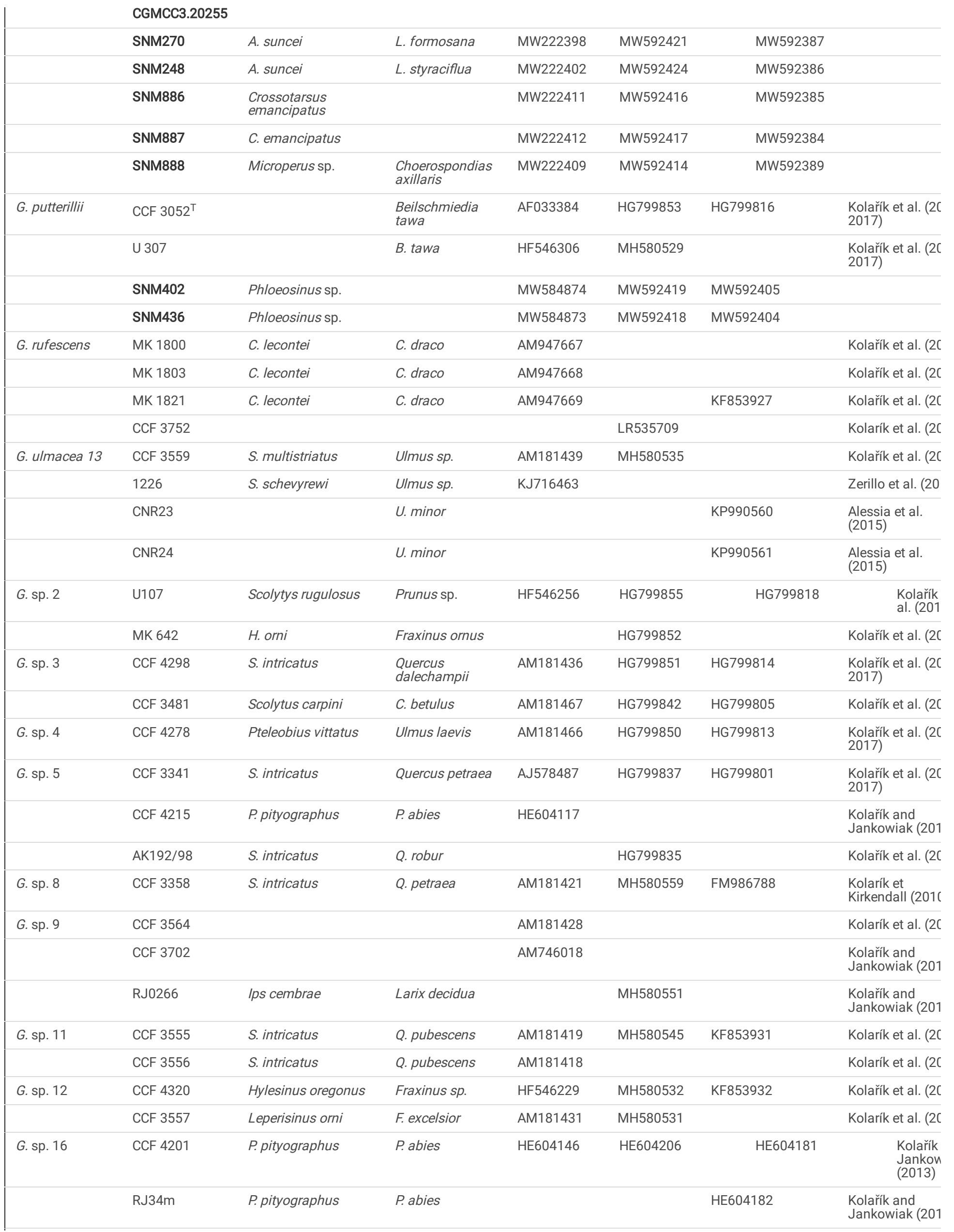




\begin{tabular}{|c|c|c|c|c|c|c|c|}
\hline \multirow[t]{2}{*}{ G. sp. 19} & CCF 3658 & Hypoborus ficus & Ficus carica & AM421085 & \multicolumn{2}{|l|}{ MH580546 } & Kolařík et al. ( $2 C$ \\
\hline & CCF 3655 & H. ficus & F. carica & AM421075 & & & Kolařík et al. ( $2 C$ \\
\hline \multirow[t]{2}{*}{ G. sp. 20} & CCF 4316 & Phloesinus fulgens & $\begin{array}{l}\text { Calocedrus } \\
\text { decurrens }\end{array}$ & HF546226 & \multicolumn{2}{|l|}{ MH580547 } & Kolařík et al. ( $2 C$ \\
\hline & U193 & Scolytus schevyrewi & Ulmus pumila & HF546287 & \multicolumn{2}{|l|}{ MH580548 } & Kolařík et al. ( $2 C$ \\
\hline \multirow[t]{2}{*}{ G. sp. 21} & CCF 5270 & Scolytus oregoni & P. menziesii & HF546289 & \multicolumn{2}{|l|}{ MH580534 } & Kolařík et al. ( $2 C$ \\
\hline & CCF 4280 & H. ficus & F. carica & AM421049 & \multicolumn{2}{|l|}{ MH580533 } & Kolařík et al. $(2 C$ \\
\hline \multirow[t]{2}{*}{ G. sp. 22} & CCF 3645 & $\begin{array}{l}\text { Phloetribus } \\
\text { scarabeoides }\end{array}$ & Olea europaea & AM421061 & MH580552 & KF853941 & Kolařík et al. ( $2 C$ \\
\hline & CCF 3652 & P. scarabeoides & O. europaea & AM421062 & MH580553 & & Kolařík et al. ( $2 C$ \\
\hline \multirow[t]{3}{*}{ G. sp. 23} & CCF 3318 & Scolytid beetles & $\begin{array}{l}\text { Persea } \\
\text { gratissima }\end{array}$ & AJ578489 & & HG799808 & $\begin{array}{l}\text { Kolařík et al. }(2 C \\
2017)\end{array}$ \\
\hline & CCF 3639 & Scolytus rugulosus & $\begin{array}{l}\text { Prunus } \\
\text { armeniaca }\end{array}$ & AM421068 & HG799838 & HG799802 & $\begin{array}{l}\text { Kolařík et al. }(2 c \\
2017)\end{array}$ \\
\hline & U160 & $\begin{array}{l}\text { Scolytus } \\
\text { multistriatus }\end{array}$ & U. pumila & HF546284 & & & Kolařík et al. $(2 C$ \\
\hline \multirow[t]{5}{*}{ G. sp. 24} & MB136 & Orthotomicus erosus & Pinus halepensis & KP691926 & & KP691936 & $\begin{array}{l}\text { Dori-Bachash et } \\
\text { (2015) }\end{array}$ \\
\hline & MB242 & $\begin{array}{l}\text { Pityogenes } \\
\text { calcaratus }\end{array}$ & Pinus brutia & KP691927 & & KP691937 & $\begin{array}{l}\text { Dori-Bachash et } \\
\text { (2015) }\end{array}$ \\
\hline & MB322 & O. erosus & P. brutia & KP691928 & & KP691938 & $\begin{array}{l}\text { Dori-Bachash et } \\
\text { (2015) }\end{array}$ \\
\hline & CCF 4294 & $\begin{array}{l}\text { Pityogenes } \\
\text { quadridens }\end{array}$ & P. sylvestris & HE604165 & MH580555 & & $\begin{array}{l}\text { Kolařík and } \\
\text { Jankowiak (201 }\end{array}$ \\
\hline & MK1772 & P. pityographus & P. sylvestris & HE604164 & MH580556 & & $\begin{array}{l}\text { Kolařík and } \\
\text { Jankowiak (201 }\end{array}$ \\
\hline \multirow[t]{2}{*}{ G. sp. 25} & MK1832 & Cryphalus abietis & Abies alba & HE604128 & HE604218 & HE604186 & $\begin{array}{l}\text { Kolařík and } \\
\text { Jankowiak (201 }\end{array}$ \\
\hline & CCF 4205 & Cryphalus piceae & A. alba & HE604127 & HE604219 & HE604187 & $\begin{array}{l}\text { Kolařík and } \\
\text { Jankowiak (201 }\end{array}$ \\
\hline G. sp. 26 & CCF 4222 & Pinus sylvestris & & HE604158 & LN907595 & & $\begin{array}{l}\text { Kolařík et } \\
\text { Jankowiak (201 }\end{array}$ \\
\hline \multirow[t]{2}{*}{ G. sp. 27} & CCF 4206 & $\begin{array}{l}\text { Pityogenes } \\
\text { bidentatus }\end{array}$ & P. sylvestris & HE794978 & HG799839 & & Kolařík et al. ( $2 C$ \\
\hline & CCF 4605 & Pityophthorus sp. & $\begin{array}{l}\text { Pinus } \\
\text { ponderosae }\end{array}$ & HF546309 & & HG799827 & $\begin{array}{l}\text { Kolařík and } \\
\text { Jankowiak (201 }\end{array}$ \\
\hline G. sp. 29 & CCF 4221 & C. piceae & A. alba & HE604125 & HE604233 & HE604184 & $\begin{array}{l}\text { Kolařík and } \\
\text { Jankowiak (201 }\end{array}$ \\
\hline G. sp. 30 & CCF 4288 & I. cembrae & L. decidua & HE604132 & HE604216 & HE604193 & $\begin{array}{l}\text { Kolařík and } \\
\text { Jankowiak (201 }\end{array}$ \\
\hline G. sp. 31 & CCF 4196 & P. pityographus & P. sylvestris & & HE604230 & HE604176 & $\begin{array}{l}\text { Kolařík and } \\
\text { Jankowiak (201 }\end{array}$ \\
\hline \multirow[t]{2}{*}{ G. sp. 32} & CCF 3554 & Phloeosinus thujae & $\begin{array}{l}\text { Chamaecyparis } \\
\text { pisifera }\end{array}$ & AM181426 & HG799874 & HG799885 & $\begin{array}{l}\text { Kolařík et al. }(2 C \\
2017)\end{array}$ \\
\hline & CCF 5242 & Phloeosinus sequiae & S. serpervirens & HF546265 & HG799873 & HG799886 & $\begin{array}{l}\text { Kolařík et al. }(2 C \\
2017)\end{array}$ \\
\hline G. sp. 33 & CCF 4598 & Scolytus praeceps & Abies concolor & HF546331 & HG799869 & HG799831 & Kolařík et al. ( $2 C$ \\
\hline \multirow[t]{2}{*}{ G. sp. 34} & CCF 4604 & Ips plastographus & C. decurrens & HF546295 & HG799866 & HG799826 & Kolařík et al. ( $2 C$ \\
\hline & U417 & S. praeceps & A. concolor & HF546330 & HG799868 & HG799830 & Kolařík et al. (2C \\
\hline G. sp. 35. & U196 & Pityophthorus sp & P. menziesii & HF546231 & & HG799823 & Kolařík et al. ( $2 C$ \\
\hline \multirow[t]{2}{*}{ G. sp. 36} & CCF 4328 & Pityophthorus sp. & Pinus muricata & HF546236 & & & Kolařík et al. ( $2 C$ \\
\hline & MK1814 & & Cedrus atlantica & & MH580538 & & present study \\
\hline G. sp. 37 & U197 & Pityophthorus sp. & P. menziesii & HF546288 & HG799862 & HG799824 & Kolařík et al. (2C \\
\hline G. sp. 38 & U79 & $\begin{array}{l}\text { Pseudopityophthorus } \\
\text { pubipennis }\end{array}$ & $\begin{array}{l}\text { Notholithocarpus } \\
\text { densiflorus }\end{array}$ & HF546346 & MH580537 & & Kolařík et al. ( $2 C$ \\
\hline
\end{tabular}




\begin{tabular}{|c|c|c|c|c|c|c|c|}
\hline & CCF 5241 & P. pubipennis & Quercus acrifolia & HF546251 & MH580536 & & Kolařík et al. ( $2 c$ \\
\hline G. sp. 39 & U323 & Pjuglandis & Juglans hindsii & HF546314 & & KC222335 & Kolařík et al. ( $2 C$ \\
\hline \multirow[t]{2}{*}{ G. sp. 40} & CCF 5250 & Pityophthorus sp. & Pinus ponderosa & HF546273 & MH580550 & & Kolařík et al. (2C \\
\hline & CCF 5245 & I. plastographus & Pinus radiata & HF546304 & MH580549 & & Kolařík et al. ( $2 C$ \\
\hline \multirow[t]{4}{*}{ G. sp. 41} & U215 & C. pubescens & Artemisia & HF546292 & HG799865 & HG799825 & Kolařík et al. ( $2 C$ \\
\hline & & Cossoninaesp. & & & & & \\
\hline & CCF 4342 & Bostrichidae sp. & $\begin{array}{l}\text { Toxicodendron } \\
\text { diversilobum }\end{array}$ & HF546249 & HG799871 & HG799833 & Kolařík et al. (2C \\
\hline & U64 & Scobicia declivis & $\begin{array}{l}\text { Umbellularia } \\
\text { californica }\end{array}$ & HF546342 & HG799870 & HG799832 & $\begin{array}{l}\text { Kolařík } \\
\text { al. (201 }\end{array}$ \\
\hline \multirow[t]{2}{*}{ G. sp. 42} & U166 & $\begin{array}{l}\text { Phloesinus } \\
\text { canadensis }\end{array}$ & $\begin{array}{l}\text { Chamaecyparis } \\
\mathrm{sp} .\end{array}$ & HF546279 & HG799860 & HG799821 & Kolařík et al. ( $2 C$ \\
\hline & CCF 5251 & S. rugulosus & Prunus sp. & HF546285 & HG799861 & HG799822 & Kolařík et al. (2C \\
\hline G. sp. 43 & CCF 4203 & Pityogenes knechteli & P. ponderosae & HF546223 & HG799864 & & Kolařík et al. ( $2 C$ \\
\hline \multirow[t]{2}{*}{ G. sp. 44} & CCF 4333 & Pityophthorus sp. & Pinus sabiniana & & LN907598 & & Kolařík et al. (2C \\
\hline & CCF 4332 & Pityophthorus sp. & P. sabiniana & & LN907599 & & Kolařík et al. ( $2 C$ \\
\hline \multirow[t]{3}{*}{ G. sp. 45} & Hulcr 17004 & $\begin{array}{l}\text { Pityophthorus } \\
\text { annectens }\end{array}$ & Pinus taeda & & MH580482 & & present study \\
\hline & Hulcr 17006 & P. annectens & P. taeda & & MH580487 & & present study \\
\hline & Hulcr 18823 & $\begin{array}{l}\text { Pityophthorus } \\
\text { pulicarius }\end{array}$ & P. taeda & & MH580505 & & present study \\
\hline \multirow[t]{3}{*}{ G. sp. 46} & Hulcr 11575 & $\begin{array}{l}\text { Pseudopityophthorus } \\
\text { minutissimus }\end{array}$ & $\begin{array}{l}\text { Quercus } \\
\text { laurifolia }\end{array}$ & MH426748 & MH580479 & & present study \\
\hline & Hulcr 18077 & $\begin{array}{l}\text { Hypothenemus } \\
\text { eruditus }\end{array}$ & J. nigra & MH426766 & MH580490 & & present study \\
\hline & Hulcr 18201 & H. eruditus & J. nigra & MH426776 & MH580501 & & present study \\
\hline \multirow[t]{2}{*}{ G. sp. 47} & Hulcr 11904 & H. dissimilis & Q. laurifolia & MH426749 & MH580480 & & present study \\
\hline & Hulcr 19182 & H. dissimilis & $\begin{array}{l}\text { Carya } \\
\text { illinoinensis }\end{array}$ & MH426789 & MH580510 & & present study \\
\hline \multirow[t]{2}{*}{ G. sp. 48} & Hulcr 19190 & $\begin{array}{l}\text { Phloeosinus } \\
\text { dentatus }\end{array}$ & $\begin{array}{l}\text { Juniperus } \\
\text { virginiana }\end{array}$ & MH426796 & MH580514 & & present study \\
\hline & Hulcr 19192 & P. dentatus & J. virginiana & MH426797 & MH580515 & & present study \\
\hline $\begin{array}{l}\text { Emericellopsis } \\
\text { pallida }\end{array}$ & CBS $490.71^{\mathrm{b}}$ & Pityophthorus sp. & & NR_145052.1 & KC998998.1 & KC987138.1 & $\begin{array}{l}\text { Grum-Grzhimay } \\
\text { et al. (2013) }\end{array}$ \\
\hline
\end{tabular}

Note. Isolates recovered in present study are in bold. a G. pallida selected as outgroup of phylogenies. T = ex-type isolates.

Table 3 Summary of the variability between species of the Geosmithia jiulianshanensis species complex. Numbers of changes (substitutions and indels) and corresponding

relative percentage dissimilarity values are presented

\begin{tabular}{|lllllll|}
\hline Species & \multicolumn{2}{l}{ ITS rDNA (531 bp) } & TEF1-a (899 bp) & \multicolumn{2}{l|}{ TUB2 (496 bp) } \\
\cline { 2 - 7 } & G. jiangxiensis & G. jiulianshanensis & G. jiangxiensis & G. jiulianshanensis & G. jiangxiensis & G. jiulianshanensis \\
\hline G. formosana & $5(0.94 \%)$ & $4(0.75 \%)$ & $5-6(0.56-0.67 \%)$ & $5(0.56 \%)$ & $3(0.60 \%)$ & $4(0.81 \%)$ \\
\hline G. jiangxiensis & & $5(0.94 \%)$ & & $8-9(0.89-1.0 \%)$ & $4(0.81 \%)$ \\
\hline
\end{tabular}

Table 4 After 8 days of culture in MEA medium, the colony diameter (unit: $\mathrm{mm}$ ) of Geosmithia jiulianshanensis species complex and Geosmithia pulverea at different temperatures. 


\begin{tabular}{|lllll|}
\hline Species/T & G. formosana & G. jiangxiensis & G. jiulianshanensis & G. pulverea \\
\hline $5^{\circ} \mathrm{C}$ & $\bigotimes 1$ & 1 & $1.5-4$ & 0 \\
$20^{\circ} \mathrm{C}$ & $50-54$ & $50-58$ & $59-64$ & $23-29$ \\
$25^{\circ} \mathrm{C}$ & $58-64$ & $59-69$ & $65-78$ & $30-37$ \\
$30^{\circ} \mathrm{C}$ & $44-52$ & $49-60$ & $66-70$ & $31-36$ \\
$35^{\circ} \mathrm{C}$ & $\approx 0$ & $1-4$ & $11-14$ & $1.5-4$ \\
$37^{\circ} \mathrm{C}$ & 0 & 0 & $\otimes 1$ & 0 \\
\hline
\end{tabular}

\section{Figures}

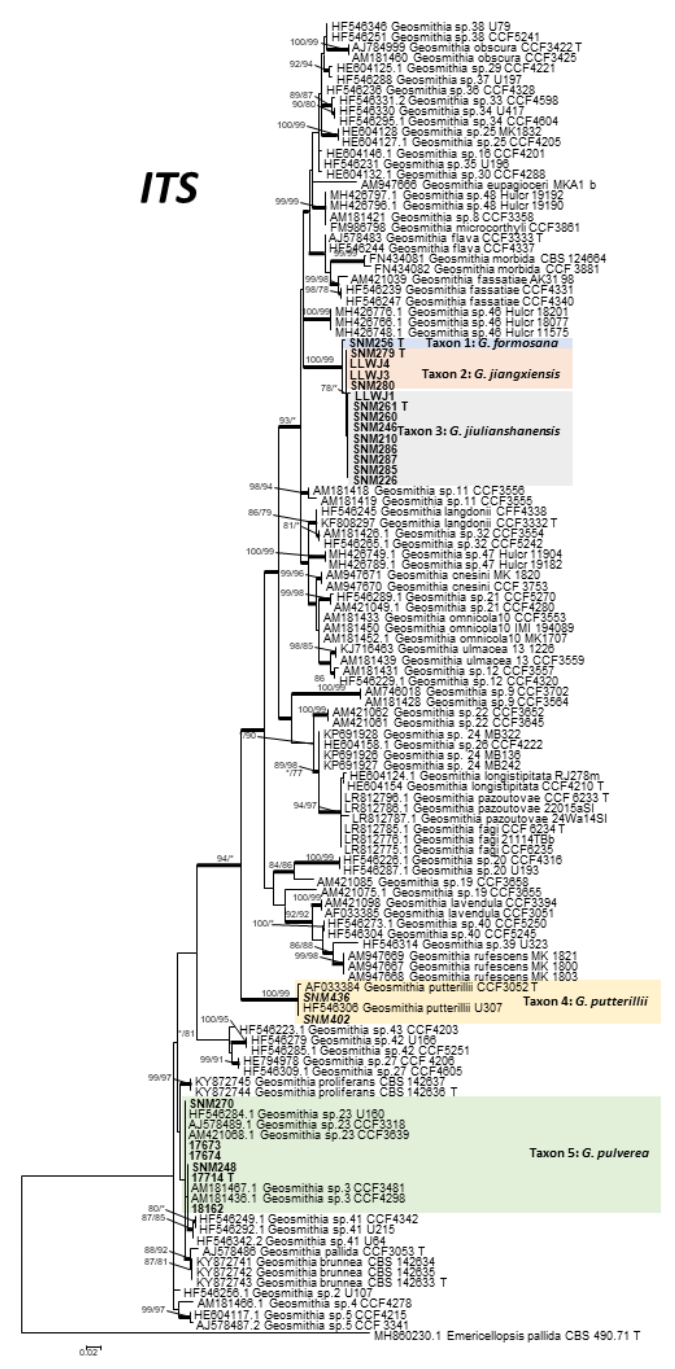

Figure 1

ML tree of Geosmithia generated from the ITS sequence data. Sequences generated from this study are printed in bold. Bold branches indicate posterior probability values $\geq 0.9$. Bootstrap values of $\mathrm{ML} / \mathrm{MP} \geq 75 \%$ are recorded at the nodes. $\mathrm{T}=$ ex-type isolates 


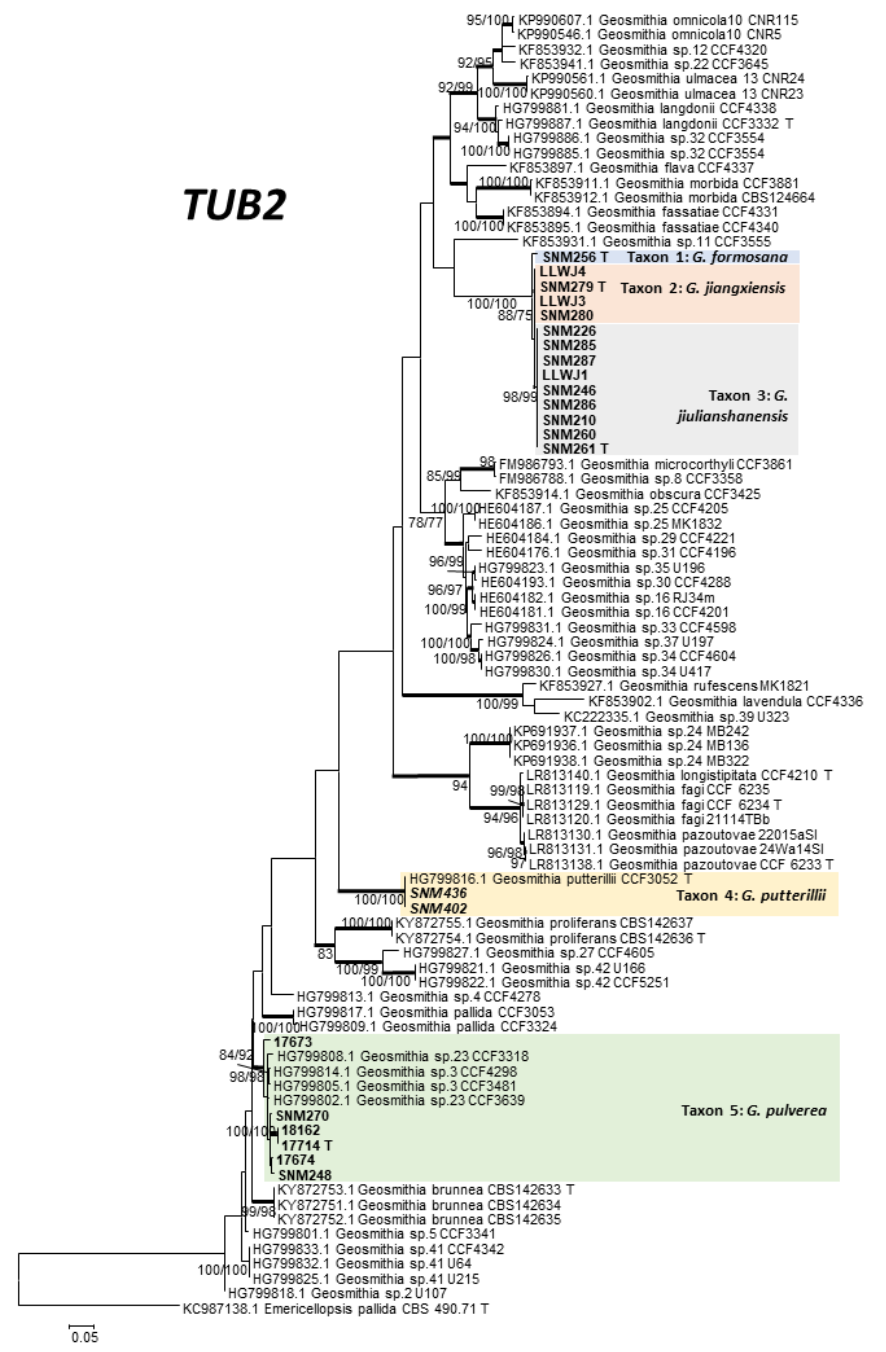

Figure 2

$\mathrm{ML}$ tree of Geosmithia generated from the TUB2 sequence data. Sequences generated from this study are printed in bold. Bold branches indicate posterior probability values $\geq 0.9$. Bootstrap values of $\mathrm{ML} / \mathrm{MP} \geq 75 \%$ are recorded at the nodes. $T=$ ex-type isolates 


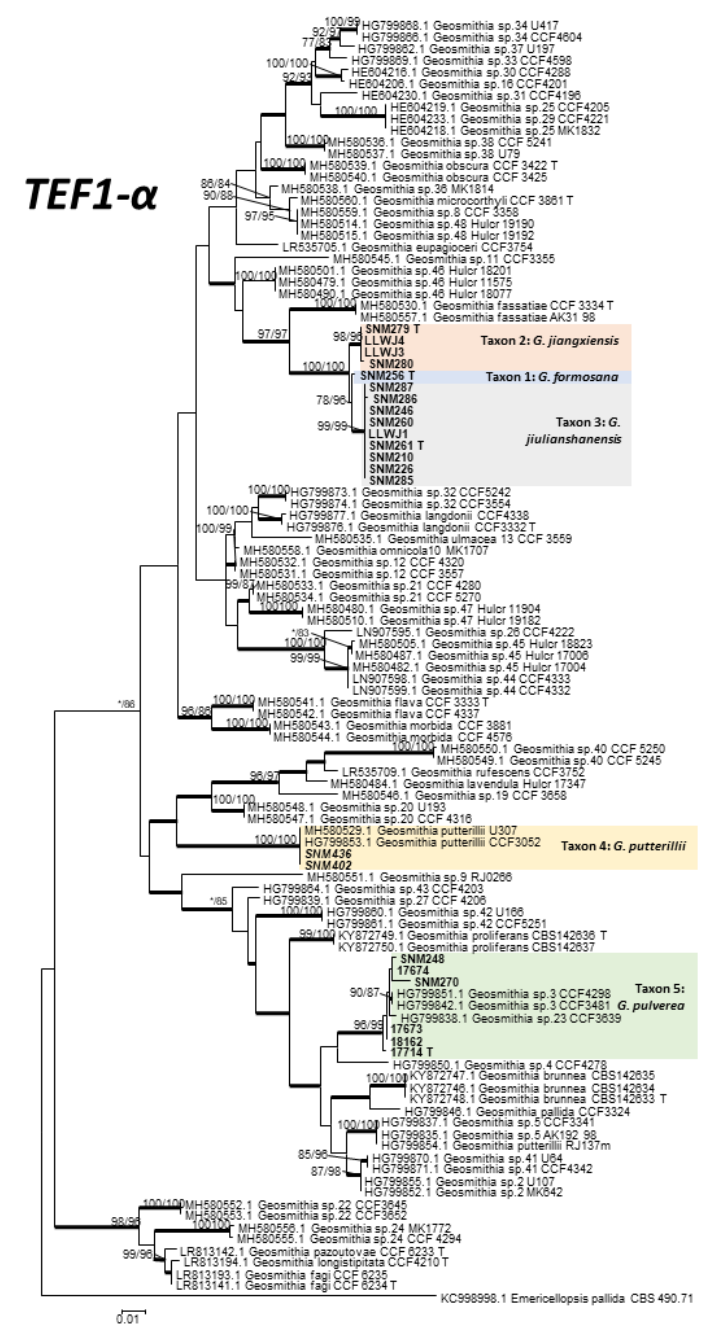

\section{Figure 3}

ML tree of Geosmithia generated from the TEF1-a sequence data. Sequences generated from this study are printed in bold. Bold branches indicate posterior probability values $\geq 0.9$. Bootstrap values of $\mathrm{ML} / \mathrm{MP} \geq 75 \%$ are recorded at the nodes. $T=$ ex-type isolates 

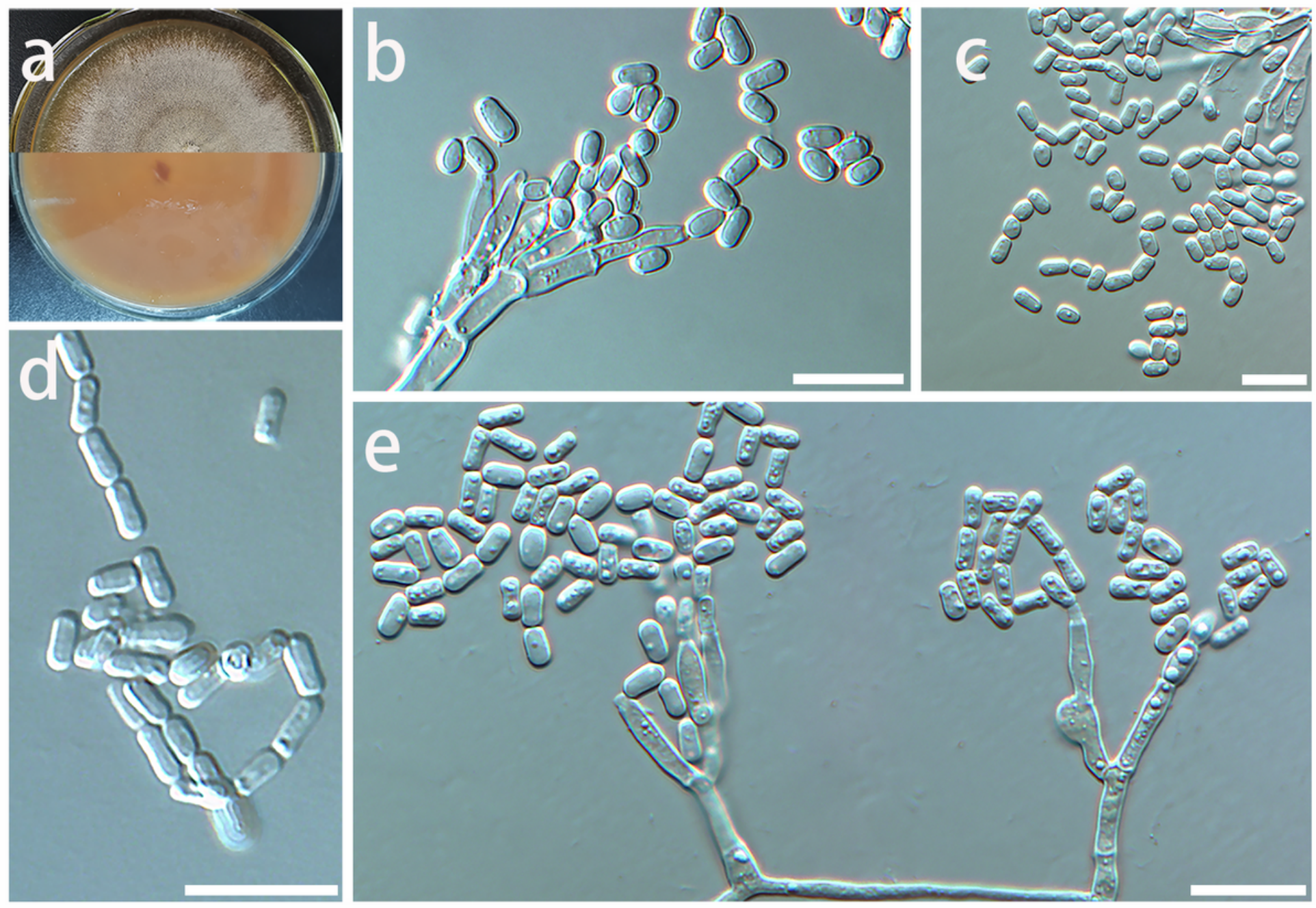

\section{Figure 4}

Morphological characters of Geosmithia jiulianshanensis sp. nov. (CGMCC3.20252) a. 8 days old culture on 2\% MEA; b-e. Conidiophores and conidia. Scale bars: $b-e=10 \mu m$ 

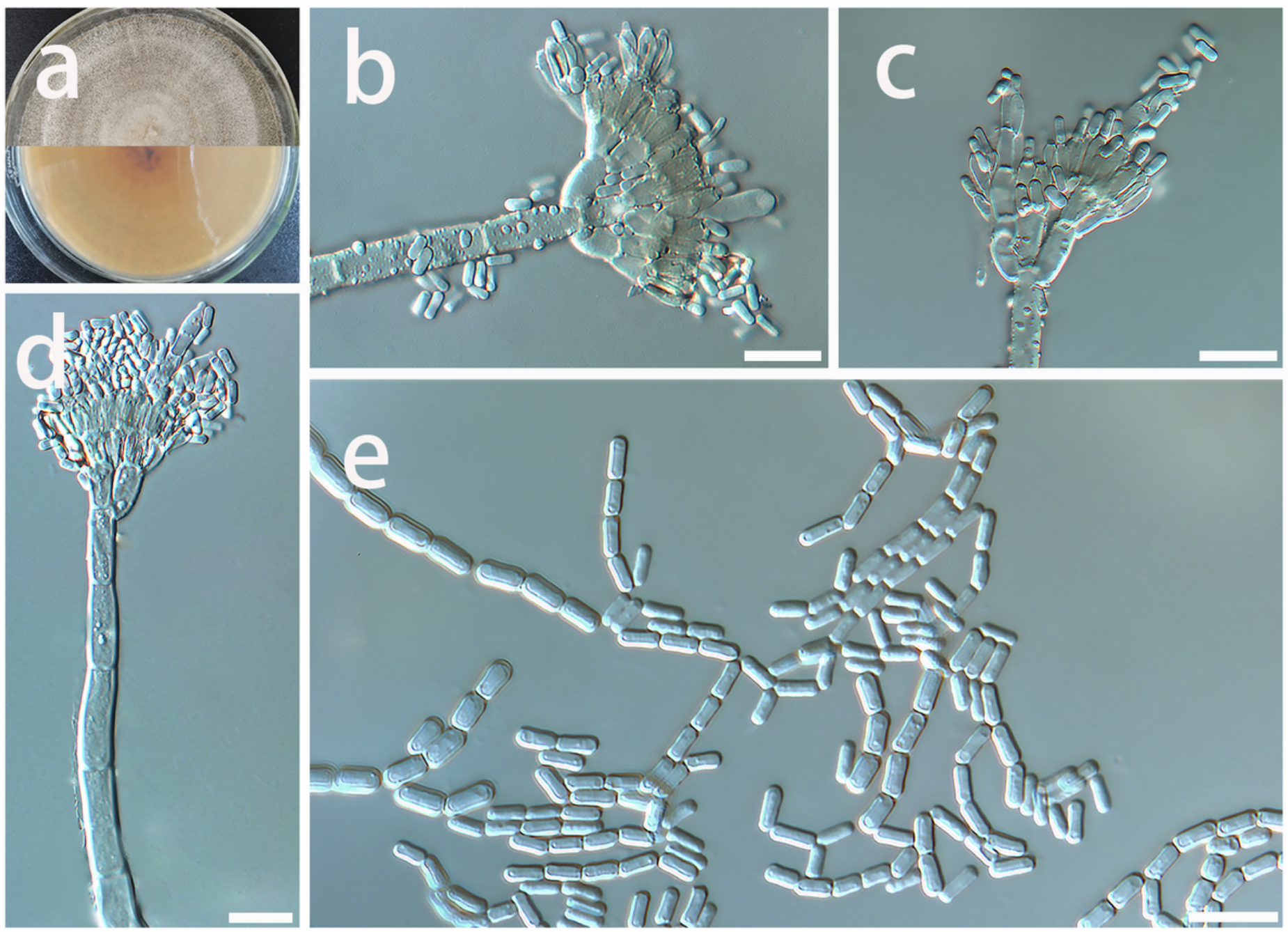

Figure 5

Morphological characters of Geosmithia jiangxiensis sp. nov. (CGMCC3.20253) a. 8 days old culture on 2\% MEA; b-e. Conidiophores and conidia. Scale bars: $b-d=10 \mu m, e=20 \mu m$ 

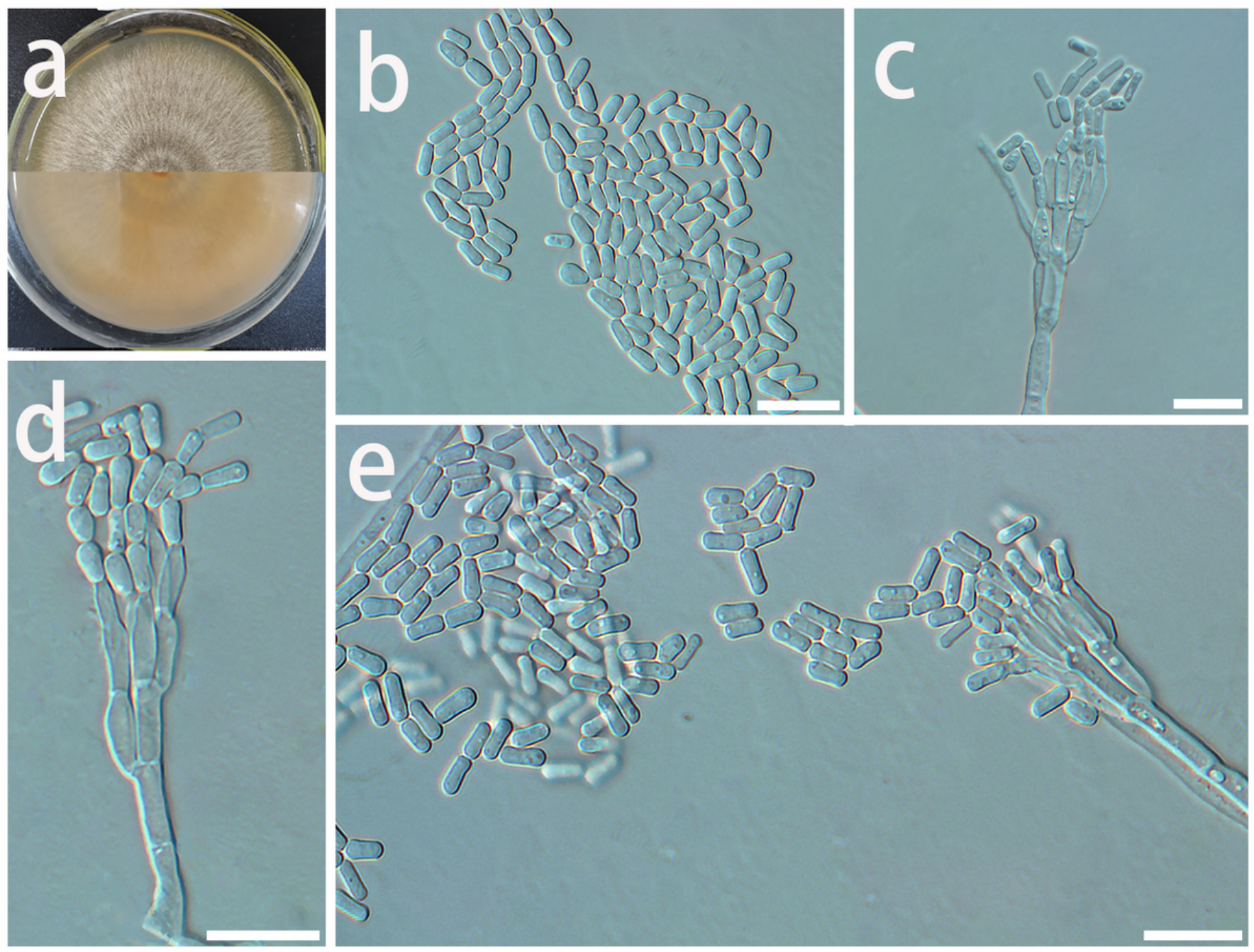

Figure 6

Morphological characters of Geosmithia formosana sp. nov. (CGMCC3.20254) a. 8 days old culture on 2\% MEA; b-e. Conidiophores and conidia. Scale bars: $\mathrm{b}-\mathrm{e}=10 \mu \mathrm{m}$ 


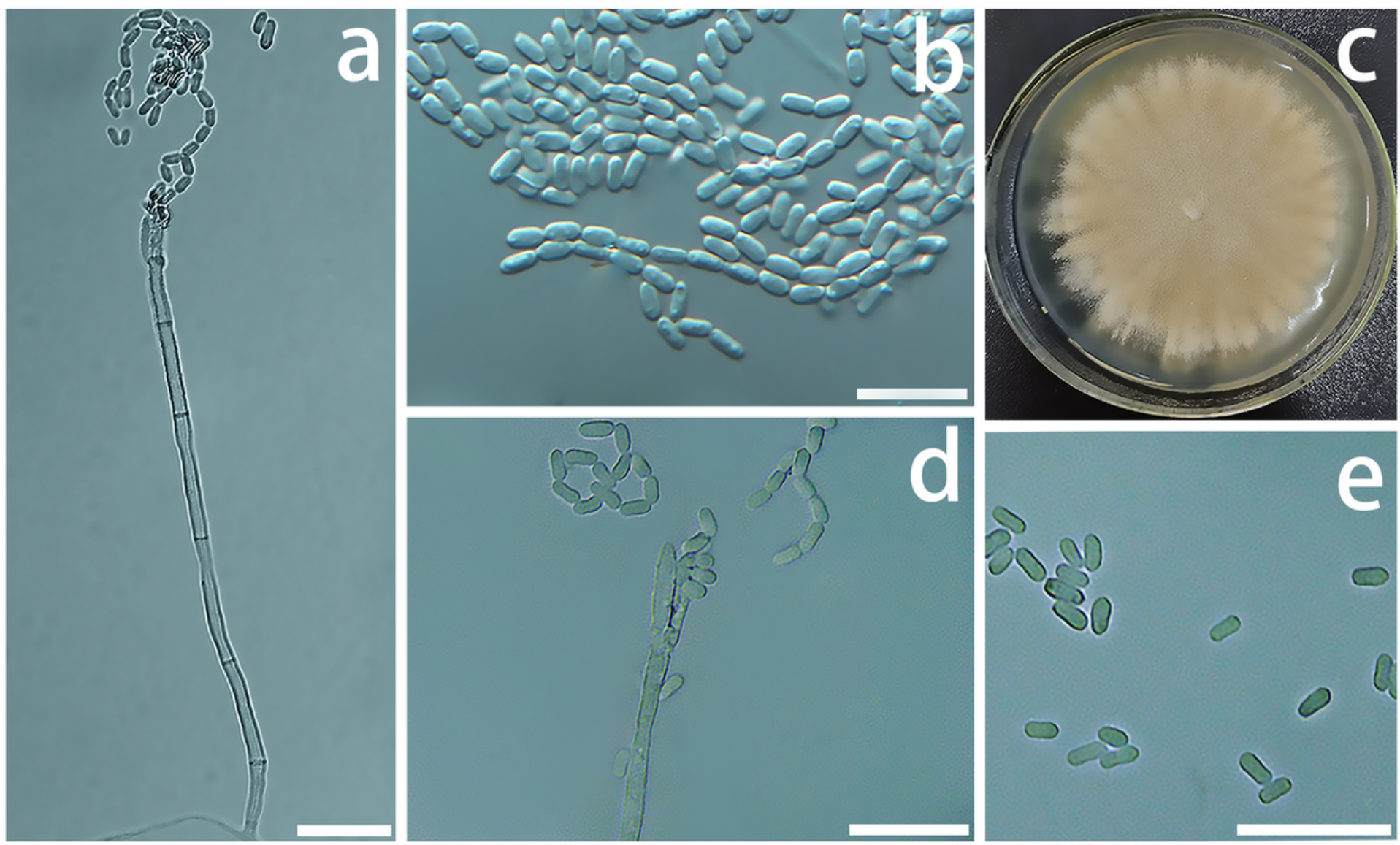

Figure 7

Morphological characters of asexual structures of Geosmithia pulverea sp. nov. (CGMCC3.20255) a. 8 days old culture on 2\% MEA; b-e. Conidiophores and conidia. Scale bars: $b-e=10 \mu \mathrm{m}$ 